
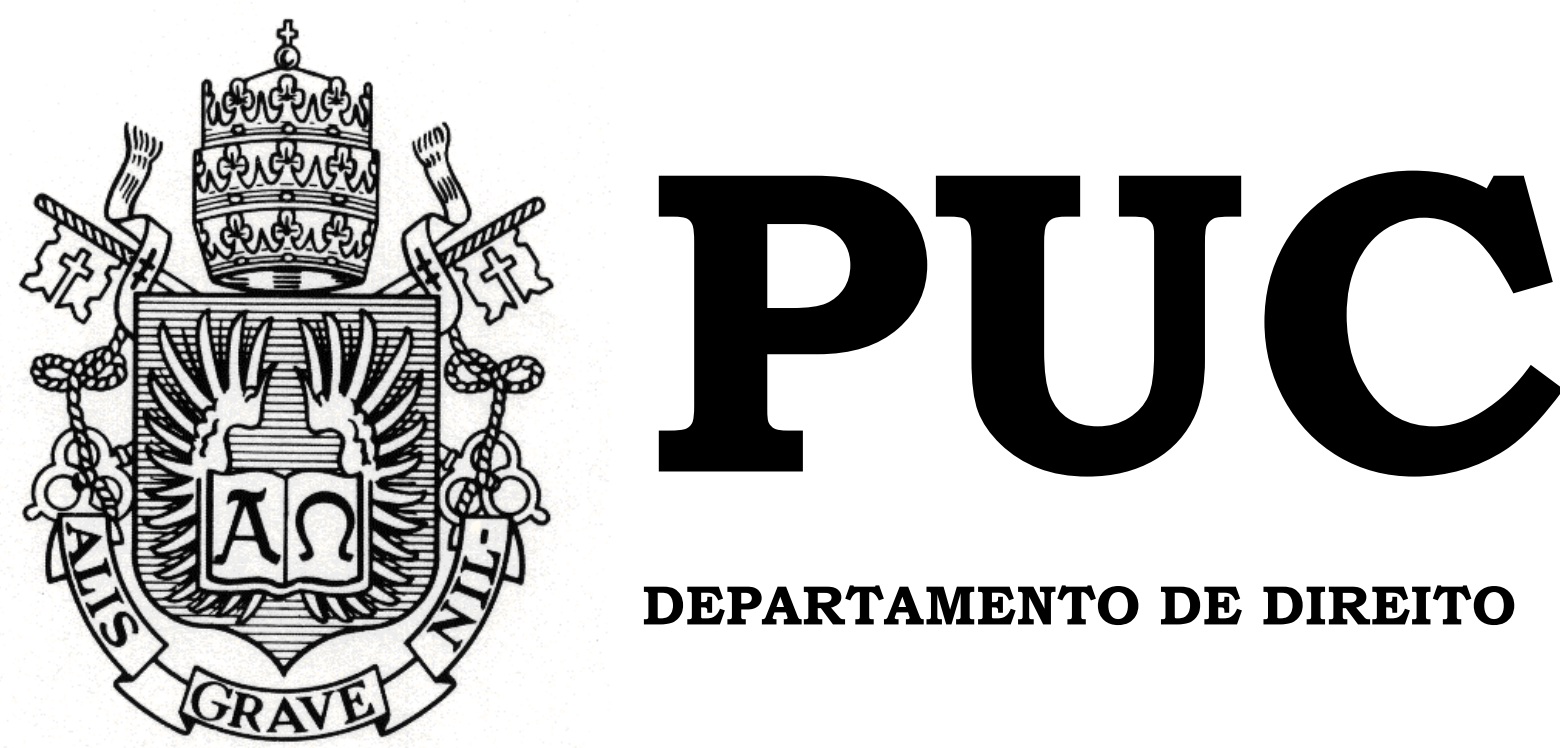

DEPARTAMENTO DE DIREITO

\title{
CARREGO PAPAI NO BOLSO?
}

por

Marilia Alves de Carvalho e Silva

ORIENTADOR: Profa. Inês Alegria Rocumback 2012.1

PONTIFÍCIA UNIVERSIDADE CATÓLICA DO RIO DE JANEIRO RUA MARQUÊS DE SÃO VICENTE, 225 - CEP 22451-900 RIO DE JANEIRO - BRASIL 


\section{“CARREGO PAPAI NO BOLSO?”}

por

"MARILIA ALVES DE CARVALHO E SILVA"

Monografia

apresentada

ao

Departamento de Direito da Pontificia Universidade Católica do Rio de Janeiro (PUC-Rio) para a obtenção do Título de Bacharel em Direito.

Orientador: Profa. Inês Alegria Rocumback 


\section{AGRADECIMENTOS}

A escolha do Direito de Família como tema não foi aleatória, mas reflexo da minha imensa admiração e respeito pelas pessoas que, apesar de nunca terem entendido muito bem a minha opção de graduação, sempre seguiram ao meu lado. Por isso, agradeço primeiramente aos meus pais, Ana e Raul.

À outra pessoa que completava o meu convívio diário, minha irmã Carolina, eu agradeço por tornar o cotidiano mais alegre com suas risadas escandalosas e carinho incondicional.

Igualmente importante é o apoio e compreensão do meu namorado e parceiro Vítor Alves, que pacientemente não apenas compreende minhas constantes ausências, como também ilumina meu caminho com a sua presença. Obrigada por acreditar em mim quando o cansaço me abate, pelas críticas sinceras e por compartilhar comigo o sonho de um futuro.

Agradeço ainda a Dra. Márcia Prudente e ao Erick Seara, por terem despertado em mim a paixão pelos inúmeros problemas e casos complicados de uma Vara de Família.

Também não poderia deixar de agradecer a Professora Inês Alegria Rocumback, não apenas por ter ajudado a concretizar este trabalho, mas acima de tudo pela sua doçura, serenidade e paciência.

Outra pessoa a quem eu sou muito grata é a amiga Alba Lúcia Castelo Branco. Obrigada por sempre ter encontrado tempo para se fazer presente.

Por fim, gostaria de dizer "muito obrigada" a todos os amigos que não desistiram de ter a minha companhia mesmo depois de muita ausência da minha parte. 
"É comum a gente sonhar, eu sei, quando vem o entardecer

Pois eu também dei de sonhar um sonho lindo de morrer Vejo um berço e nele eu me debruçar com o pranto a me correr E assim chorando acalentar o filho que eu quero ter Dorme, meu pequenininho, dorme que a noite já vem Teu pai está muito sozinho de tanto amor que ele tem

De repente eu vejo se transformar num menino igual à mim Que vem correndo me beijar quando eu chegar lá de onde eu vim Um menino sempre a me perguntar um porque que não tem fim Um filho a quem só queira bem e a quem só diga que sim Dorme menino levado, dorme que a vida já vem Teu pai está muito cansado de tanta dor que ele tem

Quando a vida enfim me quiser levar pelo tanto que me deu Sentir-lhe a barba me roçar no derradeiro beijo seu E ao sentir também sua mão vedar meu olhar dos olhos seus Ouvir-lhe a voz a me embalar num acalanto de adeus Dorme meu pai sem cuidado, dorme que ao entardecer Teu filho sonha acordado, com o filho que ele quer Ter".

O Filho Que eu Quero Ter Toquinho e Vinicius de Moraes 


\section{RESUMO}

O presente trabalho pretende, primordialmente, demonstrar a possibilidade de incidência dos danos morais nas hipóteses em que o pai protela culposamente a investigação de paternidade ou abandona afetivamente o rebento.

Tem-se como base para o estudo duas situações: a primeira é aquela em que o genitor, apesar da existência de plausíveis razões que indiciam a paternidade, se vale de subterfúgios para esquivar-se das responsabilidades decorrentes do reconhecimento do rebento. A segunda situação ocorre quando, mesmo após expressa comprovação da paternidade, o pai continua rejeitando o filho.

A princípio, realizou-se uma breve retrospectiva histórico-legislativa objetivando mostrar como o Direito de Família evoluiu no país. Em seguida, procedeu-se ao estudo da repercussão dessa evolução na jurisprudência brasileira.

Estabelecido o contexto normativo e jurisprudencial, pretende-se demonstrar que indenização por danos morais faz-se necessária nas hipóteses em que se priva do filho o direito à identidade.

\section{PALAVRAS-CHAVE}

Filiação - danos morais - paternidade - direito a identidade. 


\section{ABSTRACT}

The following work intend to demonstrate the possibility of the incidence of moral damages on the hypotheses in which the father defer the inquiry of parentage, affectively abandon his child, or even denies paternity ties.

This research has it's foundation on two main propositions. First is when the father intentionally avoids parental responsabilities, despite reasonable indications of parenthood link. The second situation is when, even after the confirmation of the existence of the link, the father insists on continuing to reject his child.

Initially, it is presented a brief historical-legislative retrospective objectvating to show the evolution of Family Law in Brazil. Hereupon, the casework analyses the influence of this evolution on the brazilian jurisprudence.

Once established the normative and jurisprudential context, it is meant to evince the obligation of idenmification for moral damages when the child is deprived of it's right to have a parental identity.

\section{KEY-WORDS}

Affiliation - moral damages - paternity - identity right 


\section{SUMÁRIO}

INTRODUÇÃO

CAPÍTULO 2: O DIREITO DE FAMÍLIA E O DIREITO DAS

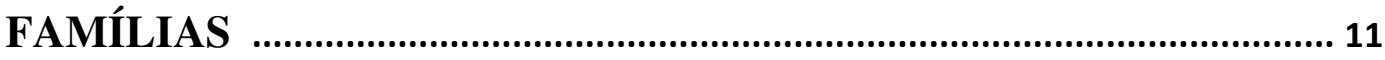

2.1. Evolução Histórica …………………………………………………...11

2.2. Evolução do cenário jurídico ................................................................... 13

2.3. Panorama do Direito de Família Atualmente ………………………..... 15

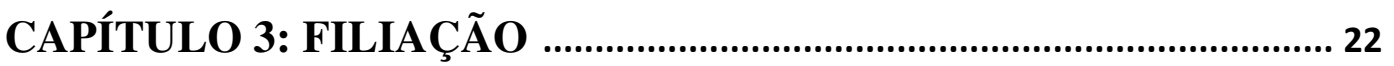

3.1. A Presunção pater is est quem justae nuptia demonstrant .................22

3.2. Evolução Científica: Novos Horizontes ………………………………...24

3.3. A Paternidade Afetiva ………………………………………………….... 27

CAPÍTULO 4: A CONFIGURAÇÃO DO DANO MORAL …………... 31

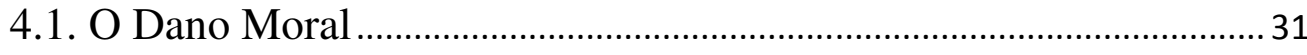

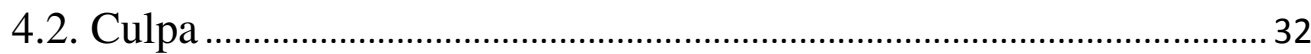

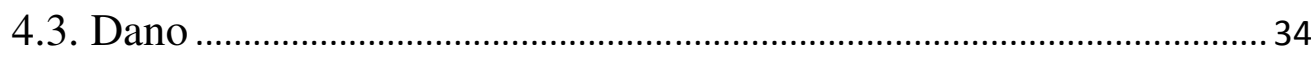

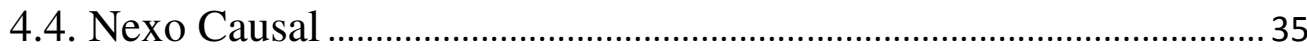

4.5. O Dano Moral Aplicado às Relações de Família: A Tese de Maria Celina Bodin de Moraes................................................................................... 36

CAPÍTULO 5: DANOS MORAIS NAS HIPÓTESES DE INVESTIGAÇÃO DE PATERNIDADE E ABANDONO AFETIVO . 39

5.1. Deveres Inerentes ao Poder Familiar …………………………………... 39

5.2. A Conduta Protelatória na Ação de Investigação de Paternidade .41

5.3. Danos Morais por Abandono Afetivo do Pai Adimplente de

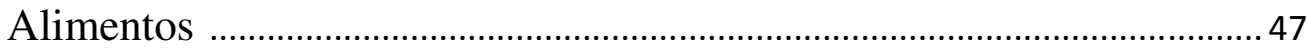

5.4. O Julgamento Paradigmático ................................................................. 52

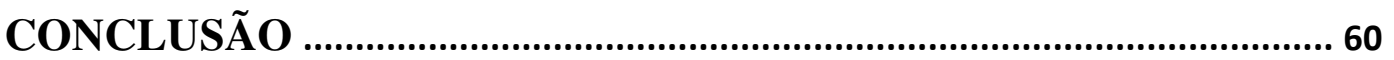

REFERÊNCIAS BIBLIOGRÁFICAS ....................................................... 62 


\section{INTRODUÇÃO}

Vivemos em um país onde o Censo Escolar de 2009 identificou que 4.869.363 (quatro milhões oitocentos e sessenta e nove mil trezentos e sessenta e três) crianças e adolescentes matriculados em escolas têm apenas o nome da mãe no registro de nascimento (BRASIL, 2009). Este dado expressa a quantidade alarmante de crianças que já iniciam sua trajetória com o estigma de "filhos de pais desconhecidos", alijados de seu direito a identidade.

O que as estatísticas apontam é fruto de três condutas igualmente danosas: a primeira é aquela do pai que procrastina a demanda de investigação de paternidade, visando dissimular a verdade; a segunda atitude reprovável é a do progenitor que, após o resultado positivo de paternidade, insiste na negação do progênito; e por fim também merece ser repreendido o pai que assume esse vínculo por afetividade e, posteriormente, busca desconstituir tal relação.

Combinada a conduta irresponsável do genitor está a jurisprudência brasileira, que é vacilante ao reconhecer a possibilidade de reparação civil nos casos citados acima. Isto cria uma reação em cadeia: pais que negam à prole sua identidade pessoal e não sofrem qualquer punição, gerando uma sensação de impunidade, o que aumenta a legião de filhos de pais desconhecidos. Segundo feliz síntese de Maria Berenice Dias:

\footnotetext{
Enquanto não for reconhecido que o direito prevalente é do filho, com a adoção de mecanismos eficazes para que o pai assuma os deveres decorrentes do poder familiar, a sociedade continuará sendo conivente com a irresponsabilidade masculina. A conta quem paga é o Estado que não pode se furtar de cumprir o comando constitucional de assegurar a crianças, adolescentes e jovens, com absoluta prioridade, todos os direitos inerentes à cidadania. (DIAS, 2012, s/p).
} 
Nesse contexto, é necessário salientar que a sociedade, principalmente nas últimas décadas, tem se tornado cada vez mais plural e dinâmica. Esses aspectos se refletem no instituto familiar, que atualmente assume composições variadas que fogem à organização tradicional da família de tempos pretéritos. Tendo isso em vista, é possível perceber a necessidade de adaptação do direito às novas formas de organização familiar da sociedade contemporânea.

Dessa forma, vale ressaltar alguns fatos que contribuíram para a mudança social: o novo papel assumido pela mulher, o desgaste da família matrimonial, patriarcal e heterossexual, a ausência do dever de procriar e de coabitar e o abandono do casamento como a única forma legítima de constituir um lar. Todos estes fatores, que foram melhor abordados no capítulo 1, contribuíram para uma transformação no ordenamento jurídico.

Tais mudanças normativas tiveram como expoente o advento da Constituição Federal de 1988 e do Código Civil de 2002, que inauguraram um novo panorama normativo e hermenêutico. Estes diplomas foram a representação da aceitação de novas práticas sociais, que antes eram disciplinadas por leis esparsas ou relegadas à ausência de regulamentação.

Assim, o Direito Civil contemporâneo, mais especificamente o Direito de Família, impregnado dos valores presentes em nossa Carta Magna, possui como norteadores os seguintes princípios: Igualdade na Chefia Familiar, Solidariedade, Igualdade entre Cônjuges e Companheiros e Dignidade da Pessoa Humana.

No contexto legislativo, também é importante mencionar que recentemente foram incluídos no ordenamento dois provimentos que tentam melhorar o problema do desconhecimento ou negação da paternidade. São os Provimentos 12 e 16 do Conselho Nacional de Justiça, de 2010 e 2012, respectivamente. Ainda que a ideia tenha potencial para trazer benefícios, a 
forma como disciplina a situação deixa muito a desejar, conforme é observado no capítulo que trata do tema.

A evolução do panorama normativo é abordada mais profundamente ainda no capítulo 2 da presente pesquisa. No entanto, tornou-se necessário mencionar desde logo os novos princípios e a primazia do afeto na interpretação e resolução dos litígios.

Tendo em mente as transformações no direito e na sociedade, é oportuno esclarecer que o conceito de filho também se modificou. De acordo com o novo panorama social e jurídico seria inconcebível permanecer o entendimento de que o pai é exclusivamente o marido da mãe, como ocorria no passado. Assim, se procedeu a um estudo aprofundado sobre o tema da filiação no capítulo 3.

A despeito dessa nova realidade familiar baseada na afetividade, muitos pais e mães seguem negando aos filhos o direito à identidade, protelando ou impossibilitando o reconhecimento da paternidade. Ademais, também assusta que nos dias atuais os genitores permaneçam negando cuidado e afeto aos seus rebentos.

Em função disso, o presente estudo tem o objetivo de discutir a possibilidade de o filho pleitear ação indenizatória pela recusa de seu reconhecimento ou por abandono afetivo, indagando se esta rejeição por parte de quem deveria amar caracterizaria um dano moral.

É oportuno esclarecer que o dano moral é amplamente discutido na doutrina, conforme foi analisado no capítulo 4. Para possibilitar uma melhor compreensão do instituto, foram expostos os elementos que compõe a responsabilidade civil subjetiva, de forma a tentar demonstrar os parâmetros para que um ato injusto gere o dever de indenizar. O capítulo reserva ainda um espaço para tratar do posicionamento de uma importante jurista sobre os danos morais aplicados nas relações de família. 
Após esta abordagem dos aspectos gerais do instituto, o capítulo 5 ocupa-se em restringir o estudo para os danos morais decorrentes da negação consciente do reconhecimento da filiação ou do abandono afetivo Em seguida, o mesmo trata da possibilidade de reconhecimento de danos morais por abandono afetivo do pai adimplente de alimentos.

Para tanto, procedeu-se a uma análise jurisprudencial e doutrinária sobre o assunto. Buscando evitar uma abordagem maniqueísta, foram expostos posicionamentos contrários e favoráveis ao reconhecimento do direito a indenização pela privação do direito de ter o nome paterno.

No que tange a abordagem da jurisprudência, também foi imperioso analisar o polemico acórdão exarado pelo Superior Tribunal de Justiça, que teve grande repercussão no início do mês de maio ao condenar o pai a pagar $\mathrm{R} \$ 200.000,00$ (duzentos mil reais) a título de indenização por abandono afetivo.

Nesse contexto de constante necessidade de ponderar e mediar opiniões opostas, merece referência especial a indagação feita pela professora Maria Celina Bodin de Moraes:

Como fazer para aplacar o avanço inexorável da lei do mercado no âmbito das relações existenciais, ou, de maneira mais sucinta: como evitar que os sentimentos se tornem simples mercancias? Uma das respostas a esta questão já foi dada: o Direito de Família tem seus próprios remédios e estes é que devem ser fortalecidos. (MORAES, 2004, p. 414).

Esta pertinente provocação da professora é o que o presente estudo busca ajudar a responder. Obviamente sem a pretensão de abranger todas as espécies de relações familiares, mas tendo como foco aquelas em que o rebento que não é reconhecido ou é rejeitado.

Portanto, tendo em mente a primazia do interesse do menor, a pesquisa que ora se inicia espera chegar à conclusão de que é possível e necessária a aplicação de danos morais nas hipóteses de rejeição paternofilial. 


\section{CAPÍTULO 2 - O DIREITO DE FAMÍLIA E O DIREITO DAS FAMÍLIAS}

\section{1 - Evolução Histórica}

"É impossível ser feliz sozinho". A letra da música "Wave”, de Tom Jobim, nos remete à ideia de que os seres humanos se unem para alcançar a felicidade. No entanto, se hoje considera-se que o afeto é o elo fundamental para a união, no passado este pensamento poderia ser tido como uma mera licença poética.

Por muito tempo as famílias se formaram para proteger interesses meramente patrimoniais, visando assegurar o fluxo de transmissão de bens das classes mais abastadas. Nesse contexto, toda autoridade era exercida pelo patriarca, que desempenhava as funções de chefe político, sacerdote e juiz.

Esta família patriarcal e formada por interesses eminentemente patrimoniais é a primeira de que se tem registro certo e incontestável. Antes disso, há referências esparsas de que, em estados primitivos, este instituto era baseado na promiscuidade e na organização matriarcal. Menos importantes para o Direito, os estágios iniciais de família não merecem enfoque no estudo em tela.

Por outro lado, o breve exame histórico da civilização romana é indispensável para posteriormente compreendermos o contexto legislativo brasileiro. Isto se justifica porque a família brasileira no século XIX ainda guardava muitas características que se assemelhavam com os moldes romanos.

Nesta civilização, a mulher era considerada incapaz, passando do domínio do pai para o poder do marido. Conforme colaciona Caio Mário: 
"Casada, saía de sob a potestas do pai e ingressava in domo mariti, ali se prolongando a sua condição de subalterna, pois que entrava in loco filiae e desta sorte perpetuava-se a sua inferioridade" (PEREIRA, 2010, p. 13).

Sendo a mulher considerada inferior, o varão era quem detinha toda a autoridade, exercendo seu poder sobre os filhos, a mulher e o patrimônio familiar, respectivamente chamados de pátria potestas, manus potestas e domenica potestas (PEREIRA, 2010, p. 29). O fato de o instituto familiar ser todo moldado com base nessa autoridade do homem é o que permite afirmar que a família era patriarcal.

A família também sofria forte influência da religião, o que contribuiu imensamente para o poder do Império Romano. Os reflexos disso no Brasil puderam ser sentidos durante séculos, considerando que "até o advento da República, em 1889, a única forma de casamento era o religioso.” (DIAS, 2010, p. 143).

Apesar de as regras terem se tornado menos severas com o passar dos anos, a organização romana da família manteve-se centrada na autoridade do paterfamilias. Assim, o poder era sempre exercido pelo homem, a quem a esposa e a prole deviam obediência.

Avançando na história pós-romana, a eclosão das duas Guerras Mundiais consistiu em um marco importante que impulsionou uma mudança de paradigma. Houve a necessidade de os homens irem para a guerra, o que fez com que as mulheres assumissem funções até então exclusivas dos varões. (PEREIRA, 2010, p.14).

Além disso, a Revolução Industrial também contribuiu para uma nova posição da ala feminina da sociedade. Com a crescente demanda por mão de obra, tornou-se imperioso que as mulheres ingressassem no mercado de trabalho. 
Em função dessa alteração, a posição de subordinação feminina tornou-se incompatível com a nova realidade social, uma vez que a mulher passou a contribuir com a subsistência da família.

Corroborando com este novo modelo familiar, havia também um novo espaço de convivência: as cidades. Nestas, o espaço era mais reduzido que no campo, o que levava a uma maior interação entre seus membros, fortalecendo os vínculos afetivos.

Dessa forma, o molde familiar autocrático e despótico foi substituído pela concepção democrático-afetiva da família. Paulatinamente, o cenário em que vigorava o domínio paterno sobre tudo e todos se transformou em um espaço dominado pelo afeto e respeito mútuos.

\title{
2.2 - Evolução do cenário jurídico
}

Como afirmado no tópico anterior, a concepção de família mudou. No entanto, essas mudanças não se operaram sozinhas, considerando que foram causa e efeito de diversas transformações que se operaram no Direito. Por isso, justifica-se a abordagem histórica feita inicialmente, conforme defendem Gama e Guerra:

\begin{abstract}
A família não está dissociada dos fatores exógenos que a cercam, recepcionando acontecimentos e fenômenos que, num primeiro momento, não se relacionariam ao contexto familiar. Sabe-se, na atualidade, que um enfoque exclusivamente jurídico sobre temas de Direito de Família certamente representa visão estreita e falha sobre as famílias no Direito. (GAMA \& GUERRA, 2007, p. 116).
\end{abstract}

Através da análise do cenário histórico, busca-se mostrar como o afeto foi deixando de ser uma mera abstração para se tornar um norteador de interpretações do meio jurídico.

Inicialmente, em uma época onde vigorava uma notória inter-relação entre a Igreja e o Estado, é evidente que apenas o casamento religioso era admitido, conforme já se mencionou. 
O Código Civil de 1916 refletia essa mentalidade, reconhecendo no casamento a coluna vertebral da estrutura familiar, conforme se observa na redação do artigo 229 deste diploma legal: "Criando a família legítima, o casamento legitima os filhos comuns, antes dele nascidos ou concebidos".

Considerando que o matrimônio tinha como foco a proteção das classes mais ricas, a procriação era um dever consequente da obrigatoriedade de manter relações sexuais. Diametralmente oposto a isso, os filhos concebidos fora do casamento eram discriminados, sendo chamados de filhos bastardos ou adulterinos.

Dessa forma, em um Código Civil que reservava 151 dos 290 artigos para tratar de interesses patrimoniais, torna-se evidente que os filhos "adulterinos" ficavam exilados de qualquer proteção. Maria Berenice Dias esclarece oportunamente: "As referencias feitas aos vínculos extramatrimoniais e aos filhos ilegítimos eram punitivas e serviam exclusivamente para excluir direitos, numa vã tentativa de preservação do casamento" (DIAS, 2010, p. 30).

Este cenário começou a ser alterado com a Lei 883, de 21 de outubro 1949, que dispôs sobre a possibilidade de reconhecimento dos filhos “ilegítimos". Em seu artigo primeiro, o diploma possibilitava que, após a dissolução da sociedade conjugal, os genitores pudessem reconhecer os filhos concebidos fora do casamento. Esta mesma lei estendeu o direito de pleitear a ação de reconhecimento também ao filho.

Entretanto, uma alteração mais significativa veio mais tarde, com a promulgação da Lei 4.121, de 27 de agosto de 1962, que instituiu o Estatuto da Mulher Casada. Com este diploma legal, a mulher adquiriu a plena capacidade, sendo-lhe assegurado também o direito aos bens reservados, aqueles obtidos exclusivamente com o seu trabalho. 
A plena capacidade e o direito aos bens reservados somaram-se ainda a outro fator legislativo que foi fundamental para a mudança do papel da mulher e consequente transformação da família: A Lei 6.615 de 1977, mais conhecida como Lei do Divórcio.

Todo este panorama legislativo já indiciava que as famílias estavam se unindo mais em virtude do afeto do que por interesse financeiro, como no passado. E toda esta visão democrática e igualitária do instituto familiar veio a ser ainda mais fortalecido com o advento de uma nova ordem constitucional, inaugurado pela Constituição Federal de 1988.

Promulgada após um período marcado pela repressão ditatorial, em que o brado retumbante foi calado e sonhos foram aprisionados, a nossa atual Carta Magna é essencialmente democrática. Os princípios que emanam desta e se irradiam por todo o ordenamento demonstram preocupação com a dignidade, igualdade e solidariedade. Estes são explorados mais profundamente a seguir, em conjunto com as modificações legislativas que sofreram sua influência.

\section{3 - Panorama do Direito de Família Atualmente}

Hodiernamente, toma cada vez mais vulto o chamado Direito Civil Constitucional, preconizando que os princípios constitucionais devem se irradiar sobre o Direto Privado, coordenando-o. A professora e advogada Beatriz Helena Braganholo ensina:

O Direito Constitucional é, mais do que nunca, responsável por regular as relações humanas, antes ditas meramente privadas e enquadradas como reguladas pelo Direito Civil. Seus interesses individuais são correspondentes a necessidades fundamentais do homem, tendo o dever de propiciar meios que levem a viver e se relacionar de uma forma mais solidária, com respeito pelo outro. (BRAGANHOLO, 2005, p. 71).

Considerando que os princípios constitucionais se irradiam por todo o ordenamento, foi dado enfoque àqueles que mais influenciam a questão 
da privação do reconhecimento da paternidade do rebento. Ao final desta breve abordagem principiológica, foi feita uma análise das leis que relacionam-se ao tema central.

O primeiro artigo de nossa Lei Maior expõe o princípio da dignidade da pessoa humana como um dos fundamentos da República Federativa do Brasil. A análise deste é retomada no capítulo que trata dos danos morais por rejeição paterna, considerando que sua complexidade transborda o objetivo do atual capítulo, que é traçar uma visão geral do direito de família na atualidade.

Por ora é importante mencionar que este preceito se irradia nos dispositivos que tratam da instituição familiar. Exemplo disso é a sua menção constitucional nos artigos 230, 227 e 226, em especial no seu parágrafo $7^{\circ}$. Isso decorre do fato de a Carta Política de 1988 ter ampliado a proteção do Estado à família.

Sabendo que os princípios se distribuem por todo o ordenamento, a Dignidade da Pessoa Humana deve receber atenção especial por se tratar de um preceito basilar, do qual derivam diversos outros.

O segundo princípio que merece referência é o da solidariedade, o qual figura como um dos objetivos de nossa República - conforme se extrai do artigo $3^{\circ}$, I da Constituição Federal. No âmbito do Direito de Família, o comportamento solidário impõe um dever de assistência material e imaterial, tendo em mente que as relações afetivas somente se sustentam onde há compreensão e cooperação. Isso decorre do fato de a família pressupor uma comunhão que deve ocorrer não apenas nos momentos felizes, como também naqueles em que há necessidade de seus integrantes se ajudarem mutuamente.

Igualmente importante é o princípio da afetividade, que deixou de ser um simples sentimento para ser erigido à categoria de valor jurídico. Esta 
ascensão foi consequência da necessidade de proteger um modelo de família eudemonista e igualitário, o que teve como consequência a maior aceitação dessas novas famílias. De acordo com Caio Mário: “A afetividade invade a ciência jurídica, transcendendo os aspectos exclusivamente psicológicos e sociológicos".

Apesar de nossa Carta Magna não ter feito menção expressa, é possível perceber a afetividade como um princípio quando se estabelece a igualdade entre a filiação biológica e a socioafetiva, e também no reconhecimento da união estável. Já o atual Código Civil foi um pouco temeroso para reconhecer o afeto como um preceito, mas ainda assim é possível perceber sua incidência nos artigos 1.511, 1.593, 1.596 e 1.604 .

O quarto princípio a ser ressaltado é o da igualdade da prole. Este é mais que um mero reflexo, caracterizando em si uma diretriz interpretativa. Sua aplicação veda qualquer distinção entre os filhos e está expressamente previsto no artigo 227, parágrafo $6^{\circ}$ da Constituição, com reflexo no artigo 1596 do Código Civil.

Por fim, cumpre mencionar o princípio do melhor interesse da criança, chamado por Rolf Madaleno de "princípio da proteção da prole". O artigo 227 de nossa Lei Maior destacou a prioridade de crianças, adolescentes e jovens terem especialmente protegidos direitos que são assegurados a todos. A preocupação específica se justifica porque são pessoas que ainda estão em formação e desenvolvimento. No Código Civil é possível perceber a influência deste preceito nos artigos 1583 e 1584 .

Exposto o panorama principiológico que foi instaurado com a Constituição Federal de 1988, cumpre elucidar as principais leis que foram promulgadas imersas nesta nova mentalidade.

Em 13 de julho de 1990 foi sancionada a lei 8.069, o Estatuto da Criança e do Adolescente, conhecido também como ECA, sua forma 
abreviada. No entanto, antes mesmo da promulgação deste diploma, a proteção à criança e ao adolescente já era objeto de preocupação. Prova disso é que a ONU aprovou a Declaração Universal dos Direitos das Crianças e em 1989 a Convenção Sobre os Direitos da Criança, as quais tinham o objetivo de criar normas que fossem aplicáveis a todas as crianças, independentemente do contexto em que estivessem inseridas. (PEREIRA, 2010, p. 45).

O Estatuto da Criança e do Adolescente, a seu turno, teve como foco a proteção e assistência a estes dois grupos de pessoas que ainda estão em formação, estabelecendo logo em seu artigo $1^{\circ}$ a Doutrina Jurídica da Proteção Integral. Além disso, estabelece também direitos, medidas de caráter administrativo e punições. Para concretizar sua finalidade, adota como técnica a descentralização através dos Conselhos.

Os direitos que figuram expressamente no Estatuto são os seguintes: direito à vida e à saúde (arts. $9^{\circ}$ ao 14); direito à liberdade, ao respeito e à dignidade (arts. 15 ao 18), direito a convivência familiar e comunitária (arts. 19 ao 52); direito à educação, cultura, esporte e lazer (arts. 53 a 59) e direito à profissionalização e a proteção no trabalho (arts. 60 a 69).

Outra medida que tenta proteger o menor é a estabelecida na lei 8.560, de 29 de dezembro de 1992, que instituiu a averiguação de paternidade dos filhos havidos fora do casamento, estabelecendo que o reconhecimento destes é irrevogável. É importante salientar que tal diploma teve parte de sua redação alterada pelas leis $n^{\circ} 12.004$ e $\mathrm{n}^{\circ} 12.010$, ambas de 2009.

A Lei $n^{\circ} 12.004$ incluiu o artigo $2^{\circ}$-A, o qual estabelece que todos os meios legais e moralmente legítimos serão capazes de provar a verdade dos fatos na investigação de paternidade. $\mathrm{O}$ parágrafo único do mesmo dispositivo dispõe ainda que a recusa do réu em realizar o exame de DNA acarretará a presunção de paternidade. 
A lei $n^{\circ} 12.010$, por sua vez, alterou o parágrafo $5^{\circ}$ do artigo $2^{\circ}$ e incluiu o parágrafo $6^{\circ}$ neste mesmo dispositivo.

Em 2002 foi publicada a lei $\mathrm{n}^{\circ} 10.406 / 02$, o atual Código Civil Apesar de ter entrado em vigor em 11 de janeiro de 2003, data posterior a da Constituição, o diploma civil vigente tramitou no Congresso Nacional antes de nossa Lei Maior. Assim, já nasceu ultrapassado, razão pela qual teve que sofrer mudanças profundas para adequar-se à realidade democrática da nova ordem constitucional.

Objetivando expor um posicionamento favorável ao diploma em análise, Rolf Madaleno faz menção a Miguel Reale, o qual sustenta que não há razão para se afirmar que o novo Código Civil é obsoleto, pois todas as oportunidades para sua atualização teriam sido aproveitadas. $\mathrm{O}$ autor defende ainda que a função de um código é normatizar apenas questões que já possuem estabilidade, ficando a cargo das leis especiais a regulamentação de situações específicas (REALE, 2005 apud MADALENO, 2011, p. 01).

Apesar disso, Rolf Madaleno, Maria Berenice Dias, Francisco José Cahali e outros importantes doutrinadores julgam ser inegável que o diploma apresenta flagrantes defasagens (MADALENO, 2011, p. 01; DIAS, 2010, p. 31). Uma relevante crítica, que é reflexo desse atraso, consiste na manutenção da clássica forma de enunciação casuística de regras, afastando a proposição de normas narrativas e diretivas. Um exemplo é a ausência de regulamentação da paternidade afetiva, fazendo com que haja necessidade de construções doutrinárias e jurisprudenciais.

Em que pese às reprovações, sua essência tem o mérito de tentar exprimir o pensamento jurídico da época democrática, ainda que às vezes de forma um pouco tímida. Um importante avanço consiste na exclusão de expressões e conceitos retrógrados que não se coadunavam com a nova realidade jurídica e a moderna organização da sociedade. 
Quanto às inovações mais recentes, é importante mencionar que o Conselho Nacional de Justiça publicou dois provimentos objetivando diminuir a quantidade alarmante de filhos de pais desconhecidos.

O primeiro foi o Provimento 12, publicado em 2010, que instituiu o Programa Pai Presente. A regulamentação determina que seja remetido para as Corregedorias Gerais dos Tribunais de Justiça o nome e o endereço dos alunos matriculados nas escolas sem paternidade reconhecida. As corregedorias, por sua vez, devem repassar a cada juiz informações relativas às suas comarcas, com o fito de iniciar o procedimento de investigação de paternidade instituído pela Lei 8.560. Desde então, iniciativas para regularizar esta situação se difundiram por nosso país.

A outra novidade é o Provimento 16, de fevereiro do presente ano, considerado uma consequência direta da medida que foi exposta no parágrafo anterior. O novo documento dispõe acerca do procedimento que deve ser obedecido no caso de a mãe ou o filho maior de idade comparecerem perante os Oficiais de Registro Civil das Pessoas Naturais para indicação do suposto pai. O Oficial deve preencher o termo que consta em documento anexo ao Provimento e remeter ao Juiz Corregedor Permanente, ou ao magistrado da comarca definido como competente.

Feito isso, a primeira hipótese é o genitor confirmar a paternidade, situação que não apresenta maiores transtornos. Nesse caso, apenas se lavrará um termo de reconhecimento e posteriormente será encaminhada a certidão ao Oficial da serventia em que tenha sido feito originalmente o registro, para realizar a averbação.

O problema reside na hipótese de o suposto pai negar a paternidade que lhe é atribuída ou não atender à notificação judicial no prazo de 30 (trinta) dias. Se isto ocorrer, ainda haverá a necessidade de se encaminhar os autos ao Ministério Público ou a Defensoria Pública para a propositura de ação investigatória de paternidade. 
A necessidade da ação de investigação de paternidade no caso de negativa ou inércia paterna após a notificação caracteriza uma flagrante falha do Provimento. Para assegurar uma maior celeridade, o Conselho Nacional de Justiça - CNJ - poderia ter estabelecido que o procedimento de notificação do genitor já supriria a necessidade deste ser citado na ação investigatória de paternidade.

Outra opção que garantiria mais eficácia à disposição do CNJ seria a utilização da mediação, ou seja, uma tentativa de concretizar um acordo entre as partes sem que haja a necessidade de instauração de um processo. $O$ fato de a lide em tela envolver sentimentos faz com que a prática mediativa seja a mais indicada. Dessa forma, seria afastada a necessidade de um processo judicial, que separaria ainda mais aqueles que nunca tiveram a oportunidade de estreitar um vínculo afetivo.

Toda essa evolução legislativa, consideravelmente mais acentuada após a Constituição Federal de 1988, demonstra que o Direito não está dissociado dos fatos sociais, ao contrário, deve servir para regulamentar a vida. Assim, deve-se sempre continuar buscando formas de adequar as normas aos anseios da civilização. Por essa razão se justifica a análise do dano moral como uma tentativa de reduzir o número de pais que negam o direito a identidade de seus rebentos, causando danos a dignidade destas crianças e adolescentes. 


\section{CAPÍTULO 3 - FILIAÇÃO}

\section{1 - A Presunção pater is est quem justae nuptia demonstrant}

Conforme estudado no primeiro capítulo, ao longo de parte significativa do século XX a sociedade vivenciou a era patrimonialista do direito civil. No que tange ao tema da filiação, a preocupação com os bens familiares se verifica através da instituição da presunção pater is est quem justae nuptiae demonstrant (pai é aquele que as núpcias demonstram), positivada em nosso ordenamento pelo Código Civil de 1916 e fruto da orientação romana que considerava como pai o marido da esposa que deu a luz ao rebento.

Travestida sob uma questionável necessidade de manutenção da estrutura familiar, a pressuposição possui nítido viés patrimonialista, objetivando evitar que herdeiros estranhos ao núcleo familiar viessem a partilhar os bens com os filhos que eram considerados "legítimos". A outra finalidade era assegurar a fidelidade e coabitação do casal, impedindo que relações extra-matrimoniais se tornassem publicamente conhecidas.

Tendo em mente o momento histórico em que a presunção foi criada, torna-se possível compreendê-la melhor: a visão sacralizada de família, a obrigação de a mulher casar virgem, a proibição do trabalho feminino e o fato de a esposa ficar confinada em casa cuidando das tarefas domésticas faziam com que a idéia de adultério feminino fosse praticamente inimaginável. Sendo assim, deduzia-se que o filho só poderia ter como pai o marido de sua mãe.

Por isso, se construiu um estado ficto de filiação, onde a verdade biológica cede lugar a um entendimento de que apenas os frutos do casamento constituem a prole juridicamente protegida. De acordo com a oportuna lição de Maria Berenice Dias: "Despreza o legislador a verdade 
biológica e gera uma paternidade jurídica" (DIAS, 2010, p. 346). Dessa forma, à filiação matrimonializada eram garantidos todos os direitos pelo simples fato de terem nascido naquela estrutura onde havia um consórcio entre um homem e uma mulher unidos pelo casamento.

Diametralmente oposta era a condição dos filhos concebidos por genitores que não eram casados, os quais eram exilados de qualquer direito relativo à sua ascendência paterna. Segundo o ensinamento de Vanessa R. C. Sampaio Souza: "Chancelava a lei a discriminação dos filhos ilegítimos que, tão biológicos quanto os legítimos, não poderiam, em sua maioria, ser juridicamente considerados como tais" (SOUZA, 2005, p. 61).

Portanto, eram os rebentos que sofriam as consequências das faltas cometidas pelos genitores, sendo catalogados como ilegítimos, legítimos e legitimados. Os primeiros eram novamente classificados em naturais ou espúrios, e por fim os espúrios se dividiam em incestuosos e adulterinos. Oportuno esclarecer que o Código Civil de 1916 estabelecia que os filhos incestuosos e adulterinos não poderiam ser reconhecidos, comprovando que "a situação conjugal do pai e da mãe refletia-se na identificação dos filhos" (DIAS, 2010, p. 347).

Somente com a promulgação do Decreto-lei 4.737, em 1942 e da Lei 883 de 1949 foi possível o reconhecimento do filho que não havia sido gerado no seio da família matrimonializada, o que só seria viável após o término do casamento do genitor.

Entretanto, o marco definitivo foi a nossa Constituição Federal de 1988, a qual garante a igualdade de direitos dos filhos, conforme previsão expressa do artigo 227, § $6^{\circ}$ : "Os filhos, havidos ou não da relação do casamento, ou por adoção, terão os mesmos direitos e qualificações, proibidas quaisquer designações discriminatórias relativas à filiação". 
Apesar da vedação constitucional ao tratamento discriminatório e da possibilidade de determinar a relação de filiação biológica, nosso atual Código Civil insiste na utilização de presunções, conforme se extrai de seu artigo 1.597:

Art. 1597: Presumem-se concebidos na constância do casamento os filhos:

I- nascidos cento e oitenta dias, pelo menos, depois de estabelecida a sociedade conjugal;

II- nascidos nos trezentos dias subsequentes à dissolução da sociedade conjugal, por morte, separação judicial, nulidade e anulação do casamento;

III- havidos por fecundação artificial homóloga, mesmo que falecido o marido;

IV- havidos, a qualquer tempo, quando se tratar de embriões excedentários, decorrentes de concepção artificial homóloga;

V- havidos por inseminação artificial heteróloga, desde que tenha prévia autorização do marido.

É preciso, portanto, abandonar ideias pré-concebidas que vigoravam em uma época em que era impossível verificar cientificamente a paternidade. Hodiernamente, o desenvolvimento da ciência não apenas possibilita que se resolvam antigos problemas, como também introduz novas tecnologias que, por sua vez, acabam criando novas perguntas, conforme é abordado a seguir.

\section{2 - Evolução Científica: Novos Horizontes}

Não há dúvidas de que o exame de DNA foi o fator decisivo para possibilitar a comprovação ou negação da paternidade, mas é importante relembrar que outras mudanças mais sutis ocorreram anteriormente.

O primeiro progresso importante foi a descoberta dos grupos e fatores sanguíneos, o que ocorreu por volta de 1900, tendo como responsável o imunologista e patologista Karl Landsteiner. Com isso, se tornou possível a exclusão da paternidade quando não fosse encontrada correspondência entre as propriedades encontradas no sangue do suposto genitor e do possível rebento. 
Em seguida, desvelou-se o sistema HLA, Human Leucocyte Antigen, possibilitando a análise dos antígenos que se localizam nas células nucleadas do corpo humano. Tal procedimento tornou possível negar a paternidade de 95 em cada 100 indivíduos apontados como possíveis genitores.

Dando continuidade a evolução científica, foi descoberta a estrutura do DNA, o que proporcionou a James Watson e Francis Crick o premio Nobel em 1962. Porém, foi "Alec Jeffreys, geneticista inglês, que, pesquisando o gene existente no músculo humano, percebeu que havia a possibilidade de se descobrir a quem o gene pertencia. (SOUZA, 2005, p. 69)".

É importante destacar que o DNA representa a central de informações de uma célula, e não se concentra em uma parte específica do organismo. Por isso, é possível esclarecer com probabilidade de 99,999\% a paternidade que está sendo questionada. Outra vantagem é permitir que se realize a coleta do material para análise de diversos tecidos, como a saliva, o bulbo capilar, o esperma e os ossos.

O exame de DNA é alvo de algumas críticas, podendo ser citadas como exemplos: ausência de fiscalização estatal dos laboratórios que o realizam; possibilidade de falhas técnicas nas etapas do procedimento; existência de fraudes para alterar o resultado; possibilidade de falsos negativos, por influência de transplantes, além de resultados equivocados em função de falhas humanas.

A despeito das possíveis falhas, é inegável a utilidade prática e procedimental do exame. O seu advento tornou possível afirmar com proximidade da certeza a relação biológica entre o genitor e o filho. Dessa forma, ocorreu a superação da verdade formal pela verdade biológica. 
Portanto, o exame de DNA tende a ser um meio seguro de garantir a todos o conhecimento de sua ascendência genética e historicidade. Em função desta importante inovação, se destacou no cenário jurídico a busca pela identidade genética, que, a princípio, traduz a denominada verdade real nas ações em que se pleiteia o reconhecimento da paternidade. No entanto, é necessário elucidar que as transformações científicas e sociais justificam a relativização da verdade real possibilitada pelo avanço da engenharia genética.

Neste contexto, procede-se ao estudo de um método desenvolvido pela ciência que tornou mais complexa a determinação da paternidade: a inseminação artificial heteróloga.

Trata-se de uma técnica em que são inseridos espermatozoides de um doador anônimo no cérvix ou no útero da mulher. Ou seja, nesta técnica de reprodução não há o ato sexual, e o material genético pertence a um doador que não deseja ter qualquer relação com a criança que será concebida.

Corolário da total ausência de vínculo entre o doador e o ser que será gerado é o fato de o anonimato do cedente dos gametas ser um dos requisitos da prática. Somente serão fornecidas informações genéticas do doador no caso de a criança desenvolver uma doença em que se torne necessário o conhecimento das características fenotípicas do cedente, mas jamais sua identidade será revelada. É que estabelece o anexo da Resolução $\mathrm{n}^{\mathrm{o}} 1.957 / 2010$ do CFM (Conselho Federal de Medicina), no item IV, subitens 2 e 3 :

2 - Os doadores não devem conhecer a identidade dos receptores e vice-versa.

3 - Obrigatoriamente será mantido o sigilo sobre a identidade dos doadores de gametas e embriões, bem como dos receptores. Em situações especiais, as informações sobre doadores, por motivação médica, podem ser fornecidas exclusivamente para médicos, resguardando-se a identidade civil do doador.

Além do anonimato dos doadores e receptores, há outras duas condições impostas pela Resolução: a licitude e a gratuidade. Estas se 
encontram no item IV, subitem 1 do anexo do documento, conforme se observa: "A doação nunca terá caráter lucrativo ou comercial."

Concluindo, a invenção da reprodução medicamente assistida tornou possível uma forma alternativa de se gerar um bebê. Enquanto antes o genitor era o cedente do espermatozoide que fecundou o óvulo, com o desenvolvimento da inseminação artificial heteróloga tornou-se possível utilizar o material genético de um doador anônimo. Em função disso, o verdadeiro pai passou a ser aquele que se comporta como tal, doando seu amor e dedicação na criação do filho, vínculo que é conhecido como paternidade afetiva. No entanto, a paternidade afetiva não se restringe à hipótese de inseminação artificial heteróloga, incidindo em casos que não se relacionam com a ciência, o que se aborda a seguir.

\section{3 - A Paternidade Afetiva}

Enquanto as ciências técnicas buscam a solução de antigos problemas, a evolução da sociedade cria novas perguntas. Em decorrência disso, às ciências jurídicas incumbe a função de perceber e regulamentar estas novas situações.

Consequentemente, além da filiação decorrente da presunção e da filiação biológica, há a necessidade de se tutelar os interesses da filiação socioafetiva, a qual se tornou viável diante da aceitação de diversas configurações familiares. Verifica-se atualmente a existência da família socioafetiva, homoafetiva, monoparental, entre outras, além da tradicional, constituída pelo casamento. Discorrendo sobre o tema, elucida Caio Mário:

O Direito Brasileiro na contemporaneidade tem indicado novos elementos que compõe as relações familiares, transcendendo os limites fixados pela Carta de 1988, mas incorporando, também, seus princípios." (PEREIRA, 2010, p. 43).

Por hora, o estudo se cinge apenas à filiação socioafetiva, que é materializada por um conjunto de fatores que tornam possível perceber uma 
verdadeira relação afetiva entre o pai e o rebento, ainda que este não seja filho biológico ou presumido daquele. Chamado pela doutrina de posse de estado de filho, o referido conjunto de fatores compõe-se de três elementos: nominatio, tractus e reputatio (SOUZA, 2005, p. 83).

O primeiro elemento, entendido de forma restrita, consubstancia-se na utilização do patronímico paterno. Já em sentido amplo, significa o mero chamamento recíproco de pai e filho entre as partes.

O segundo, por sua vez, representa o principal requisito, pois consubstancia-se na própria relação de zelo e preocupação com a saúde, o bem estar, a educação e a formação do filho. Insta ressaltar que o uso dos meios moderados de correção não descaracteriza o elemento, e por vezes pode até evidenciá-lo ainda mais.

Por fim, reputatio significa a exteriorização da relação perante a sociedade, que se verifica quando terceiros passam a conhecer aquele conjunto como pai e filho.

Apesar de estes requisitos serem bastante utilizados, há quem considere a trilogia desnecessária por tentar traduzir com muita rigidez uma condição eminentemente afetiva. Nessa linha se encontra Luiz Edson Fachin, que leciona:

Ademais, a tradicional trilogia que a constitui (nomen, tractus e fama) mostra-se, às vezes, desnecessária, porque outros fatos podem preencher o seu conteúdo quanto à falta de algum desses elementos. É inegável, porém, que naquele tríplice elenco há o mérito de descrever os elementos normais que de modo corrente demonstram a presença da posse de estado. (FACHIN, 1996, p. 68).

Sob o prisma legislativo, apesar de a Carta Política de 1988 ter inaugurado uma hermenêutica mais democrática, o tratamento dispensado a matéria pelo atual Código Civil ainda é incipiente. Antes do advento da nova ordem constitucional, no entanto, o panorama jurídico sequer contemplava explicitamente a posse de estado, sendo esta relegada a uma 
interpretação secundária do artigo 349 do diploma civil de 1916, o qual estabelecia:

Art. 349. Na falta, ou defeito do termo de nascimentos poderá provar-se a filiação legitima, por qualquer modo admissível em direito:

I - Quando houver começo de prova por escrito, proveniente dos pais, conjuntas ou separadamente.

II - Quando existem veementes presunções resultantes de fato já certos.

Percebendo a lacuna do sistema, a doutrina se manifestava para que "a posse de estado fosse aceita como fato a corporificar uma causa de pedir nas ações de investigação de paternidade natural" (SOUZA, 2005, p. 87).

Nesse ponto, insta ressaltar que a partir da promulgação de nossa atual Lei Maior o pretérito apelo doutrinário perdeu a força, pois passou a ser vedada qualquer forma de discriminação no que tange a filiação. Em função disso, a investigação de paternidade se tornou irrestrita, posicionamento que foi seguido pelo Código Civil de 2002.

A legislação ainda não prevê de forma expressa a posse de estado de filho. Entretanto, uma interpretação ampla dos artigos 1.593; 1.596; 1.597, V e 1.603 do Código Civil permite engloba-la como uma das causas que ensejam o reconhecimento da paternidade.

A jurisprudência, a seu turno, tem se mostrado em maior consonância com a sociedade atual, reconhecendo com facilidade a paternidade socioafetiva. Nos dizeres de Adauto Tomaszewsk e Manuela Leitão:

A jurisprudência vem conferindo maior valor probatório à posse de estado de filho de maneira, às vezes, acanhada, como prova subsidiária, ou seja, vem sendo utilizada apenas como elemento de convicção do julgador a respeito de certa paternidade, e não como prova suficiente para determinar a paternidade de alguém. (TOMASZEWSK; LEITÃO; Leitão, 2006, p. 16).

No que tange à esfera constitucional, tal possibilidade está disciplinada pelo artigo 227, em seu parágrafo sexto. Neste dispositivo, é concretizada a doutrina da proteção integral, que veda qualquer distinção 
entre os filhos. Ademais, o princípio da dignidade da pessoa humana é capaz, por si só, de fundamentar a filiação socioafetiva.

No âmbito infraconstitucional, apesar de não haver previsão expressa, é possível embasar a paternidade afetiva nos artigos 1.593, 1.596 e 1.597, V, todos do Código Civil . O primeiro estabelece que o parentesco pode ser biológico ou de outra origem, podendo a filiação afetiva ser enquadrada na categoria de parentesco civil de outra origem. O segundo dispositivo, a seu turno, ratifica a igualdade entre os filhos. Por fim, o artigo 1.597, V trata dos filhos que são fruto de inseminação artificial heteróloga, que constitui uma modalidade de filiação socioafetiva.

Em suma: “(...) têm-se reconhecido outros atributos nas relações paterno-filiais. A afetividade invade a ciência jurídica transcendendo aos aspectos exclusivamente psicológicos e sociológicos." (PEREIRA, 2010, p. 43). Sendo assim, é certo que o conceito de paternidade tornou-se mais abrangente, englobando também aquele que sempre agiu como pai, assumindo um compromisso voluntário e criando um vínculo que não pode ser desprezado pelo ordenamento. 


\section{CAPÍTULO 4 - A CONFIGURAÇÃO DO DANO MORAL}

\section{1 - O Dano Moral}

As mudanças sociais e legislativas anteriormente abordadas no presente estudo impulsionaram o reconhecimento de uma espécie de dano que atinge a esfera extrapatrimonial: o dano moral. Apesar de ter sido alvo de críticas em tempos pretéritos, hodiernamente é pacífica a possibilidade de reparação civil por danos imateriais. Corroborando com o entendimento, Rolf Madaleno colacionava já em 1999:

É de Ripert a afirmação de que o dano que ontem inclinava para o nefasto azar, hoje intenta encontrar seu autor, e a infactível e conformada resignação cede espaço para a responsabilidade civil, quer pelo prejuízo material, quer incida sobre valores imateriais." (MADALENO, 1999, p. 137).

Para confirmar o relevo adquirido pelo tema, faz-se mister observar que a reparação civil por danos morais foi erigida à categoria de Direito Fundamental, previsto expressamente nos incisos $\mathrm{V}$ e $\mathrm{X}$ do $\operatorname{artigo} 5^{\circ}$ de nossa Lei Maior, conforme se observa:

Art. 5: Art. $5^{\circ}$ Todos são iguais perante a lei, sem distinção de qualquer natureza, garantindo-se aos brasileiros e aos estrangeiros residentes no País a inviolabilidade do direito à vida, à liberdade, à igualdade, à segurança e à propriedade, nos termos seguintes:

V- é assegurado o direito de resposta, proporcional ao agravo, além da indenização por dano material, moral ou à imagem;

X - são invioláveis a intimidade, a vida privada, a honra e a imagem das pessoas, assegurado o direito a indenização pelo dano material ou moral decorrente de sua violação.

Evidenciando ainda mais a possibilidade de ressarcimento pecuniário por danos imateriais, o Superior Tribunal de Justiça reconheceu a possibilidade de cumulação de danos morais e materiais provenientes do mesmo fato, entendimento consolidado na súmula 37: "São cumuláveis as indenizações por dano material e dano moral oriundos do mesmo fato".

$\mathrm{Na}$ esteira do panorama inaugurado por nossa atual Carta Política, 
também o Código Civil de 2002 reconheceu em seu artigo 927 o dever de indenizar por um dano causado a outrem em virtude de um ato ilícito. Para melhor compreensão do dispositivo, insta elucidar o conceito de ato ilícito, o que torna necessária a análise do seguinte preceito do mesmo diploma legal: “Art. 186: Aquele que, por ação ou omissão voluntária, negligencia ou imprudência, violar direito e causar dano a outrem, ainda que exclusivamente moral, comete ato ilícito."

Através do estudo deste artigo, é possível observar que o ato ilícito compõe-se de três elementos: conduta culposa contrária ao ordenamento, dano e nexo de causalidade entre o dano e a conduta. Nas palavras de Sérgio Cavalieri Filho:

Há primeiramente um elemento forma, que é a violação de um dever jurídico mediante conduta voluntária; um elemento subjetivo, que pode ser o dolo ou a culpa; e, ainda, um elemento causal-material, que é o dano e a respectiva relação de causalidade. (...) Portanto, a partir do momento em que alguém, mediante conduta culposa, viola direito de outrem e causa-lhe o dano, está-se diante de um ato ilícito, e deste ato deflui o inexorável dever de indenizar, consoante o artigo 927 do Código Civil. (CAVALIERI FILHO, 2008, p. 18).

O dever de indenizar citado por Cavalieri Filho é um corolário da responsabilidade civil, e decorre justamente da prática de uma conduta voluntária e contrária ao Direito. Tendo em mente o elemento volitivo, no presente estudo foi conferido maior enfoque ao exame da responsabilidade civil subjetiva, que tem como elemento indispensável a culpa do agente.

Uma vez citados os requisitos da responsabilidade civil subjetiva, torna-se imperioso um exame mais minucioso de cada um deles:

\section{2 - Culpa}

$\mathrm{O}$ ato ilícito, conforme visto anteriormente, tem por elemento central uma conduta voluntária contrária ao Direito, da qual se extraem dois componentes para análise: a ação ou omissão, que caracterizam o aspecto 
físico e objetivo da conduta; e a vontade, aspecto psicológico ou subjetivo. Ambos os componentes possuem relevância jurídica e são indissociáveis na caracterização do dano e do consequente dever de reparação.

A conduta culpável tem seu aspecto subjetivo na relativização do juízo de censura com base na capacidade psíquica de entendimento e autodeterminação do agente em face do caráter reprovável de sua ação ou omissão frente ao fato gerador do ato ilícito.

Assim sendo, pode-se constatar que não basta a imputabilidade do agente para que o ato seja reprovável. Assim, conclui-se que a subjetividade da responsabilização exige, além da conduta irregular, a culpa, sendo esta última, por tanto, imprescindível.

No que tange as relações paterno-filiais a culpa traduz-se na rejeição voluntária e deliberada da prole. Neste ponto, é indispensável a configuração do elemento volitivo para que se possa verificar a incidência dos danos morais. Obviamente, é impossível responsabilizar o genitor que não sabia da existência do filho ou que tem um motivo justo para não participar ativamente da vida do rebento. Sobre o tema, colaciona Giselda Hironaka:

Assim, não se há falar em culpa do não-guardião, sempre que se apresentar, por exemplo, fatores que o impedem de conviver com o filho, como será o caso da fixação do domicílio em distância considerável, que encareça os deslocamentos a fim do cumprimento do dever de educar e conviver, mormente em hipóteses de famílias menos abastadas, assim como na hipótese de doença do genitor que, a bem dos filhos, prefere se afastar para não os colocar em situação de risco, além, ainda, da comum hipótese de não se saber se, realmente, "este suposto incumprimento é imputável à própria omissão do genitor não-guardião ou aos obstáculos e impedimentos por parte do genitor guardião" (HIRONAKA, 2007, $\mathrm{s} / \mathrm{p})$. 


\section{3 - Dano}

O dano é fundamental à caracterização da reparação, uma vez que a indenização sem a sua ocorrência importa em enriquecimento ilícito a quem recebe e pena para quem paga.

Tendo em mente ser a função primordial da reparação a reintegração da vítima a seu estado anterior à prática do ato ilícito, se este não gerar nenhum prejuízo, não haverá o que ressarcir. Daí a opinião majoritária de estudiosos do tema, que defendem: “(...) o dano é não somente o fato constituinte, mas, também, determinante do dever de indenizar" (CAVALIERI FILHO, 2009, p. 71).

É importante ressaltar que, a despeito de uma interpretação antiga a qual previa o dano apenas como uma efetiva diminuição do patrimônio da vítima, atualmente entende-se dano como a lesão de um bem jurídico, qualquer que seja sua natureza, abrangendo, pois, a esfera moral do ofendido.

Respaldado pela Constituição de 1988, que consagrou a dignidade da pessoa humana como um de seus fundamentos, o dano moral ganhou maior tangibilidade e uma aplicação mais concreta ao ser conceituado como a violação a tal preceito constitucional.

Percebendo a dignidade da pessoa humana como a base de todos os valores morais e essência de todos os direitos personalíssimos, tem-se por justificada a existência própria e autônoma do dano moral, que, por tanto, não se confunde com o material, e permite-se a exigência de uma tutela jurídica independente.

Nas hipóteses de abandono afetivo e protelamento da investigação de paternidade o dano configura-se como uma ofensa a um direito da personalidade. Nos dizeres de Giselda Hironaka: 
O dano causado pelo abandono afetivo é antes de tudo um dano à personalidade do indivíduo. Macula o ser humano enquanto pessoa, dotada de personalidade, sendo certo que esta personalidade existe e se manifesta por meio do grupo familiar, responsável que é por incutir na criança o sentimento de responsabilidade social, por meio do cumprimento das prescrições, de forma a que ela possa, no futuro, assumir a sua plena capacidade de forma juridicamente aceita e socialmente aprovada. (HIRONAKA, 2007, s/p)

\section{4 - Nexo causal}

Caracteriza-se como o liame existente entre a conduta e o dano, uma vez que somente a partir da definiçãa da relação entre causa e efeito será possível determinar o grau de envolvimento do agente e a extensão de sua responsabilização pela prática do ato ilícito.

Não basta, por conseguinte, que o agente tenha praticado uma conduta ilícita; da mesma forma que não é suficiente o fato da vítima ter sofrido algum dano. É imperioso que este dano tenha sido causado pela conduta do agente, existindo, assim, uma relação de causalidade entre o comportamento e o evento ulterior.

Assim, por meio do nexo causal, é possível dizer se o resultado da prática do ato ilícito culmina em um fato danoso à vítima, o que faz dele elemento indispensável em qualquer espécie de responsabilidade civil.

No âmbito das relações familiares, este é um elemento cuja verificação é tormentosa, haja vista a dificuldade em se determinar a ligação entre a rejeição paterna e as consequências desta rejeição.

Portanto, apesar de o dano moral ser aquele insuscetível de ser quantificado pelo valor patrimonial atingido, os princípios da responsabilidade civil evoluíram. Em função dessa evolução, atualmente a reparação pecuniária é aplicável também para tutelar direitos extrapatrimoniais, atribuindo uma série de significações simbólicas ao dinheiro. 


\section{5 - O Dano Moral Aplicado às Relações de Família: A Tese de Maria}

\section{Celina Bodin de Moraes}

No primeiro capítulo foram abordados cinco princípios que permeiam as relações paterno-filiais: princípio da dignidade da pessoa humana, princípio da solidariedade, princípio da afetividade, princípio da igualdade da prole e princípio do melhor interesse da criança. Mister relembrar que estão todos previstos em nossa Lei Maior, evidenciando a preocupação do legislador constituinte com aspectos que tangem a formação moral, afetiva e psicológica do ser humano.

Conforme afirmado anteriormente, faz-se necessário retomar o exame da dignidade da pessoa humana, haja vista ser o cerne de uma tese defendida por Maria Celina Bodin de Moraes.

De acordo com o entendimento da professora, o dano moral deve ser analisado com cautela, haja vista a própria conceituação do instituto ser tormentosa.

Tendo em mente que os seres humanos são naturalmente imperfeitos, Maria Celina defende que o sofrimento, a tristeza e até mesmo a humilhação são inerentes à nossa existência terrena. Portanto, não há razão para configurar o dano moral apenas com a simples verificação desses sentimentos, sob o risco de ocorrer uma tendência à vitimização, e consequente banalização do dano moral. Nas palavras da doutrinadora:

A imperfeição é parte de nossa humanidade e, portanto, parte de nossa essência. Não há pais perfeitos, nem mães perfeitas, nem filhos, homens, mulheres ou crianças; não há deuses entre nós. (...) A vitimização é uma das características de nosso tempo, e a responsabilização excessiva é a outra face desta moeda. (PEREIRA, 2004, p. 400).

Refutando o argumento que se fundamenta na dor e no sofrimento, a professora afirma que o dano moral se configura quando há uma ofensa ao que compõe o princípio da dignidade humana. Ocorre que este princípio é 
um fundamento de nossa República, e, portanto, se irradia por diversos aspectos da ordem jurídica.

Por isso, é necessário cuidado também para não generalizar a aplicação da dignidade da pessoa humana, utilizando-o de forma indiscriminada. Na visão de Maria Celina, desumano é aquilo que reduz a pessoa à condição de objeto, afetando sua integridade psicofísica e a fazendo se sentir diminuída perante um grupo. Nas palavras da professora:

O substrato material da dignidade assim entendida deve ser desdobrado em quatro postulados: i) o sujeito moral (ético) reconhece a existência dos outros sujeitos iguais a ele; ii) merecedores do mesmo respeito à integridade psicofísica de que é titular; iii) é dotado de vontade livre, de autodeteminação; iv) é parte do grupo social, em relação ao qual tem garantia de não vir a ser marginalizado. (PEREIRA, 2004, p. 407).

No âmbito da família, a doutrinadora diferencia as relações paternofiliais e conjugais, aduzindo que nas primeiras é mais fácil se verificar a incidência de relações que dão azo a aplicação do dano moral. Nos dizeres da mesma:

Os dois tipos de relação - conjugal e filial - se diferenciam em muito, tanto estrutural quanto trivialmente; donde será mais trivial encontrar fundamentos de responsabilização por dano moral no segundo caso. Onde um tem seus fundamentos, como analise, na liberdade e na igualdade, o outro fundamenta-se na responsabilidade. Ambos remetem-se, por óbvio, à solidariedade familiar, mas de maneira muito particular. Além disso, observa-se que a questão não pode ser debatida sem que se atente para a vulnerabilidade das partes (...) (PEREIRA, 2004, p. 414).

A análise do trecho supracitado permite perceber que a proteção dos filhos também esta amparada nos demais princípios já citados, como o da solidariedade e da igualdade. Insta ressaltar que a solidariedade e a igualdade se materializam também na concessão de cuidado e a atenção a todos os filhos, para que o rebento se desenvolva e não se sinta preterido diante de seus irmãos.

Assim, negar culposamente ao rebento o conhecimento de sua identidade significa privá-lo de conhecer sua origem, atributo indissociável da personalidade, o que pode afetar sua formação psicofísica. Dessa forma, 
verifica-se uma violação ao princípio da dignidade da pessoa humana. A violação ao preceito também se observa quando o genitor rejeita conscientemente o filho biológico ou afetivo, tendo em vista que a proteção jurídica é garantida a ambos, conforme já elucidado anteriormente.

Em síntese, aquele que sofreu com a rejeição paterna voluntária teria amparo legal baseado nos princípios constitucionais, sobretudo na dignidade da pessoa humana, para buscar o reconhecimento do dano moral. 


\section{CAPÍTULO 5 - DANOS MORAIS NAS HIPÓTESES DE INVESTIGAÇÃO DE PATERNIDADE E DE ABANDONO AFETIVO}

As significações simbólicas dos valores pecuniários são mais tangíveis nas lides que envolvem o Direito de Família. Obviamente é impossível atribuir um valor ao amor ou obrigar a sentir afeto, o que faz com que a indenização extrapole a função de mero ressarcimento e adquira novos contornos, conforme se pretende demonstrar.

Apesar de ser impossível obrigar a amar, a educação e criação dos filhos são deveres decorrentes do poder familiar. Além disso, diversos princípios já mencionados buscam assegurar o integral desenvolvimento psíquico das crianças e também propiciar condições para a plena realização pessoal dos adultos. Por isso, primeiramente se procedeu a uma breve análise do instituto chamado de poder familiar para posteriormente adentrar nas hipóteses em que se defende a aplicação dos danos morais.

\section{1 - Deveres Inerentes ao Poder Familiar}

O instituto conhecido hoje como poder familiar deriva do antigo Pátrio Poder, denominação que refletia o cenário social e normativo exposto no capítulo 1 deste trabalho. Considerando que o antigo modelo de família, era baseado no princípio da autoridade justificava-se o domínio absoluto exercido pelo pater.

Porém, com a evolução da sociedade, tema que também teve assento no primeiro capítulo, os antigos moldes autocráticos de configuração familiar cederam espaço para um concepção democrática e igualitária do instituto. Assim, o foco do relacionamento deslocou-se do poder exercido 
pelo pai para a necessidade de proteger os interesses dos filhos, permitindo seu integral desenvolvimento.

Em virtude da transformação operada nas relações paterno-filiais, o atual Código Civil abandonou a expressão Pátrio Poder, vigente no diploma civil de 1916, para adotar a expressão poder familiar.

O nome utilizado, contudo, não é isento de críticas. Rolf Madaleno menciona Paulo Lôbo e Maria Clara Sottomayor para expor a visão dos que acreditam que o termo ainda carrega em si uma conotação intimamente relacionada à posse e ao domínio.

Poder familiar não é a denominação mais apropriada, porque mantém a ênfase no poder (...) assim como o termo familiar estaria deslocado do contexto, pois pode levar a acreditar que os avós e irmãos também estariam investidos da função. (MADALENO, 2011, p. 655).

Ultrapassada a problemática do nome que lhe é atribuído, é imperioso elucidar que o poder familiar é um instituto de proteção dos filhos e da família, do qual decorrem três deveres principais: dever de sustento, dever de guarda e dever de educação, previstos expressamente nos incisos I e II do artigo 1.634 do Código Civil.

O dever de sustento compreende o fornecimento de subsídios para prover as necessidades materiais dos filhos, enquanto o dever de guarda “diz ele respeito à manutenção dos filhos em companhia dos pais, ou de pelo menos um deles". (HIRONAKA, 2007, s/p). Estes não merecem esclarecimentos mais profundos por não se relacionarem diretamente com o objeto central do tema.

Prosseguindo no exame das obrigações decorrentes do poder familiar, observa-se que a educação do rebento não é mera faculdade, e sim uma imposição legal. Neste diapasão, insta ressaltar que do dever de educar deriva uma série de obrigações, tais como a escolha da escola, orientação espiritual, auxílio nos momentos decisivos e até mesmo esclarecimentos sobre assuntos sexuais e afetivos. De acordo com a lição de Caio Mário: 
Em qualquer caso, é dever inerente ao poder familiar a direção moral do filho, compreendendo os conselhos, a vigilância etc. Na falta de um critério preordenado, entende-se que aos pais cumpre preparar o filho para a vida, proporcionando-lhe obrigatoriamente a instrução primária. (PEREIRA, 2010, p. 455-456).

O conceito de educação é tão elástico e abrangente que é possível verificar a preocupação em garantir este direito em diversos dispositivos legais, como no artigo 229 de nossa Lei Maior e no artigo 22 do ECA.

Em última análise, pode-se considerar que a educação constitui a base para o integral desenvolvimento da pessoa humana, conforme corrobora Giselda Hironaka:

Por fim, o dever de educação da prole incumbe aos pais como forma de se garantir aos filhos uma perfeita conformação moral e intelectual. Os pais devem, assim, desempenhar as funções de educadores e de autoridades familiares para que a criança possa se formar enquanto pessoa humana. (HIRONAKA, 2007, p. $05)$.

Para uma interpretação coerente do poder familiar, é necessário ter em mente que o ambiente normativo da atualidade é fruto de toda trajetória descrita no capítulo 1. Assim, o dever de educação deve ser interpretado à luz dos princípios constitucionais, de forma a privilegiar a proteção de valores imateriais, como a afetividade e a solidariedade.

\section{2 - A Conduta Protelatória na Ação de Investigação de Paternidade}

No capítulo 2 foram citadas as hipóteses das crianças que nascem com o reconhecimento da paternidade já assegurado em virtude da presunção pater is est quem justae nuptiae demonstrant. É certo, todavia, que um grande número de rebentos são excluídos desta garantia, por não estarem inseridos em nenhuma das hipóteses descritas no mencionado artigo 1597 do Código Civil. 
Para tentar solucionar o problema, revelando a paternidade biológica, o exame de DNA tem se mostrado um método eficaz, possibilitando o que Rolf Madaleno chama de nova verdade na filiação.

Em decorrência da possibilidade de se verificar a paternidade biológica, o direito de se buscar o reconhecimento do estado de filiação se tornou imprescritível também para os pais. Importante ressaltar que trata-se de um direito personalíssimo, indisponível e imprescritível, previsto no artigo 27 do ECA. Sobre o tema, oportuna a lição de Rolf Madaleno:

\footnotetext{
Resultado imediato dessa nova ordem jurídica e, desse modo, da máxima de a investigatória dos vínculos genéticos ser imprescritível em qualquer direção, não mais só para o filho (art. 27, ECA), mas, igualmente, para os pais, embora na atualidade o artigo 1.601 do Código Civil admita apenas a imprescritibilidade da ação paterna de filiação. (MADALENO, 2011, p. 364).
}

Para alcançar o reconhecimento do estado de filiação, deve-se propor ação de investigação de paternidade. Nesse ponto, relembramos os Provimentos 12 e 16 do CNJ, que foram abordados no capítulo 1. Apesar de serem tentativas de garantir maior celeridade, caso o suposto pai se negue ou não responda a notificação, ainda haverá necessidade de o Ministério Público ou a Defensoria Pública ingressarem com a ação de investigatória. Assim, quando há oposição por parte do pai, os provimentos são ineficazes, pois não elidem a necessidade do procedimento judicial.

Uma vez proposta a ação, é preciso realizar a prova pericial para verificar se o autor da demanda e o réu são realmente pai e filho. Ocorre que muitas vezes o requerido se nega a realizar o exame de DNA, ou se utiliza de subterfúgios para se esquivar da perícia genética, protelando o processo.

Para tentar solucionar o problema da recusa paterna ao exame, no passado se discutia sobre a possibilidade de forçar o demandado a ceder seu material genético. Assim, se procedeu a uma ponderação de valores, onde o direito a descoberta da origem do filho não pode ficar sem aparo diante do direito a intimidade e intangibilidade física do pai. Para ilustrar o debate 
travado em tempos pretéritos cumpre expor um trecho de um livro de 2005, onde Vanessa Souza faz referencia a Maria Celina Bodin de Moraes:

Para a professora Maria Celina Bodin de Moraes, a obrigatoriedade ao exame seria medida plenamente apta à concretização da política legislativa de proteção à infância e à adolescência. A conduta do suposto pai em recusar-se à sua efetivação deveria ser qualificada como um verdadeiro abuso de direito, cujos efeitos maléficos seriam sanados através da perícia coercitiva. Para a referida autora, a integridade física constitui um verdadeiro direito da personalidade, não devendo, porém, a sua proteção ser utilizada como argumento para afastar a responsabilidade parental, porquanto aí estaria verificada a postura abusiva. (SOUZA, 2005, p. 114).

Atualmente, no entanto, a questão já está pacificada. Para conciliar os interesses das partes que compõem a lide, foi estabelecido que diante da recusa injustificada a paternidade será presumida. Tal presunção está prevista na súmula 301 do STJ, além de ter sido introduzida na lei 8.560 pela lei 12.004, diplomas legais que já receberam maior atenção no primeiro capítulo. Outrossim, este entendimento também pode ser extraído das regras gerais previstas nos artigos 231 e 232 do Código Civil.

Neste contexto, é fundamental esclarecer que a recusa ao exame deve ser analisada em consonância com o conjunto probatório, o qual deve indiciar a existência de uma relação de paternidade entre o autor e o réu.

Dessa forma, quando o réu protela a ação investigatória, ele está praticando uma conduta culposa consciente. Ocorre que o sobrenome paterno é um direito subjetivo, e a negação desse direito pode gerar no filho graves danos psicológicos, como o sentimento de rejeição, configurando o dano e o nexo causal. Com isso, se evidenciam os três elementos que caracterizam o dano moral: culpa, dano e nexo de causalidade. Nesse sentido, colaciona Rolf Madaleno:

Esse repúdio paterno imotivado ao reconhecimento do filho, cerceando-lhe voluntariamente o direito à sua identidade pessoal, representada pelo uso do nome de seu pai biológico, complemento de sua qualificação social, configura um dano moral. O pai, ao recusar o reconhecimento espontâneo do filho, com esse ilícito se opõe à felicidade do descendente, atinge e lesiona um direito subjetivo de sua prole, juridicamente resguardado, violado pela atitude reticente do reconhecimento, impedindo o descendente de contar com o seu apelido paterno, 
desconsiderando o filho no âmbito de suas relações, e assim criando-lhe inegáveis carências afetivas, traumas e agravos morais (...). (MADALENO, 2011, p. 368).

Apesar de a doutrina se posicionar de forma favorável ao reconhecimento dos danos morais no caso em tela, a jurisprudência brasileira ainda é escassa e vacilante. No entanto, há julgados em que se reconhece a litigância de má-fé, obrigando o pai a indenizar por isso.

Recentemente o Desembargador Ricardo Moreira Lins Pastl, do Tribunal de Justiça do Rio Grande do Sul, proferiu decisão nesta linha. No acórdão, foi reconhecido que o apelante R.A.M, pai do apelado R.O..., se utilizou de alegações falsas e trouxe à baila informações desnecessárias com o fito de procrastinar a demanda. Prova disso é o fato de o apelante ter afirmado que nunca teve relações sexuais com a mãe do apelado e ter feito menção a um processo criminal no qual foi absolvido do já extinto crime de sedução. Segue a ementa e um trecho do acórdão citado:

\section{APELAÇÃO CÍVEL E AGRAVO RETIDO. INVESTIGAÇÃO DE PATERNIDADE. COISA JULGADA. INOCORRENTE. PRESCRIÇÃO AFASTAMENTO. EXAME DE DNA CONCLUSIVO. LITIGÂNCIA DE MÁ- FÉ CONFIGURADA. INDENIZAÇÃO POR DANOS MORAIS. REQUISITOS NÃO CONFIGURADOS. (...)}

A toda evidência, no afã de defender-se do processo contra si instaurado, o demandado trouxe para dentro deste feito afirmações inverídicas, faltando com lealdade, pois que, em que pese lhe seja lícito apresentar a sua versão dos fatos, não lhe é permitido, em total descompasso com a boa-fé e a moral, deturpar os acontecimentos afastando-se da busca da verdade real e dificultando o trabalho do magistrado de chegar o mais próximo possível desse desiderato.

Ao fazer menção à pretérita existência da ação investigatória, "Provou a alegação!" ( fl. 352 ), e inclusive defendendo que mesmo o exame de DNA não se prestaria para provar a pretendida paternidade ( fl. 354), habilmente reitera, ainda que de forma oblíqua, aquilo que textualmente dissera naquela primeira ação (que não manteve relação sexual com a mãe do autor e ela era dada a relações múltiplas ).

E, se não bastasse isso, é incontroverso que, por duas ocasiões, o apelante não compareceu para realizar o exame de DNA, procrastinando sobremaneira o andamento do processo, trazendo, para além disso, alegações paralelas acerca de uma suposta conduta desabonatória da mãe de Rafael, que em nada colaboraram para o deslinde da causa. (TJ/RS. Oitava Câmara Cível, Apelação Cível $\mathrm{n}^{\circ}$ 70046188512, Relator. Ricardo Moreira Lins Pastl, Rio Grande do Sul, 16 fev. 2012) 
O posicionamento reticente da jurisprudência decorre do entendimento perfilhado por alguns de que a sentença que reconhece a paternidade é constitutiva. De acordo com os que adotam essa teoria, a condição de filho se inicia com o reconhecimento da paternidade.

Nesse ponto, é oportuno trazer à baila um acórdão do Tribunal de Justiça do Rio Grande do Sul, onde o Desembargador Araken de Assiss era o relator e proferiu uma decisão contrária ao reconhecimento do direito indenizatório por entender que a sentença era constitutiva:

CIVIL RESPONSABILIDADE CIVIL. DANO MORAL. ACAO MOVIDA PELO FILHO, APOS RECONHECIMENTO FORCADO DA PATERNIDADE, BUSCANDO DO PAI INDENIZACAO PELAS PRIVACOES SOFRIDAS EM VIRTUDE DA NEGLIGENCIA DESTE. IMPROCEDENCIA. 1. NAO TEM O FILHO PRETENSAO PARA HAVER DO PAI, APOS O RECONHECIMENTO FORCADO DA PATERNIDADE, INDENIZACAO PELAS PRIVACOES SOFRIDAS EM VIRTUDE DA NEGLIGENCIA DESTE, A TITULO DE DANO MORAL, PORQUE A CONDICAO DE FILHO, QUE BASEIA A DEMANDA, E EFEITO DA INVESTIGACAO ACOLHIDA. 2. APELACAO DESPROVIDA. (TJ/RS, Apelação Cível no 596125757, Rel. Araken de Assis, Rio Grande do Sul, 15 ago. 1996).

Em sentido oposto, eminentes juristas brasileiros defendem que a sentença da ação de investigação de paternidade é meramente declaratória, possuindo efeitos ex tunc. Este parece ser o posicionamento mais correto, considerando que a decisão judicial apenas certifica uma relação que existia antes, estabelecendo a paternidade de direito diante da existência incontestável da paternidade de fato.

$\mathrm{Na}$ esteira dos que afirmam que a natureza da sentença é declaratória, pode-se destacar Yussef Said Cahali, Regina Beatriz Tavares da Silva e Rolf Madaleno, o qual expõe o pensamento da primeira jurista para defender sua tese, conforme se observa:

Como salientado por Regina Beatriz Tavares da Silva, a sentença de investigação de paternidade é declaratória da afirmação da relação de filiação e tem efeito retroativo, carrega eficácia ex tunc, porque a filiação preexiste à prolação da sentença. Dessarte, a condição de filho não nasce da sentença e do seu transito em julgado, porque a decisão judicial terminativa de mérito apenas declara com a sua procedência o vínculo parental negligenciado pelo pai (...), que se esmera, por razões de puro cunho pessoal, em acentuar com o seu comportamento judicial um 
desnecessário agravo moral à identidade física, social e psíquica de seu rebento, merecendo exatamente por essa conduta responder pelo correlato e natural dever de pagar com pecúnia pelo dano moral. (MADALENO, 2011, p. 369).

O outro defensor deste posicionamento, Yussef Said Cahali, primeiramente expõe um julgado do TJRS que negou a concessão de danos morais em razão da recusa do reconhecimento da filiação. No acórdão, o Relator Souza Lima aduz que a sentença da ação investigatória é constitutiva, conforme estabelecido por Pontes de Miranda. Discordando da tese, Cahali leciona:

\begin{abstract}
Conquanto respeitável entendimento, permitimo-nos dele divergir, questionando inclusive o acerto da lição doutrinária invocada como fundamento: a ação de investigação de paternidade é eminentemente declaratória; com a sentença de procedência, o juiz limita-se à constatação da existência da relação jurídica concernente à filiação paterna; da declaração da existência desse vínculo, resulta apenas a constituição da paternité de droit; o estado filial pré existe à sentença, $\mathrm{e}$ a filiação não se constitui através desta, à força da própria lei da natureza, existente até então como simples paternité de fait (...); os deveres inerentes à paternidade devem ser cumpridos ainda que o filho não tenha sido reconhecido voluntariamente, não podendo o pai tirar proveito de sua própria malícia. (CAHALI, 2005, p. 755 - grifo do autor).
\end{abstract}

De acordo com o entendimento de Cahali, apesar de a súmula 277 do STJ dispor que os alimentos são devidos desde a citação, a paternidade de fato já é suficiente para gerar um dever moral de cuidado.

No trecho supracitado é importante destacar que o autor se refere à malícia paterna, evidenciando que o dano moral não se aplica a todas as hipóteses de ação investigatória. Para não correr o risco de responsabilizar aquele que sequer tinha conhecimento da existência de um filho seu, é necessário verificar a incidência dos elementos descritos no capítulo 3.

Na hipótese em análise, o fato gerador é o não reconhecimento espontâneo da filiação, que deve culposo. Assim, se o réu não tinha como saber que da existência do filho, não há como atribuir-lhe a responsabilidade pelo não reconhecimento, pois não terá havido uma conduta culposa. $\mathrm{O}$ dano se configura pela negação do direito à identidade, dando origem a uma série de danos psíquicos e morais. Por fim, o nexo de 
causalidade consiste nos "presumíveis traumas inferidos" (MADALENO, 2011, p. 370) pela negativa de reconhecimento.

Ao contrário de parte da jurisprudência brasileira, que insiste em adotar um posicionamento conservador, a doutrina e jurisprudência argentinas admitem com mais facilidade a possibilidade de incidência dos danos morais no caso em tela. De acordo com a corrente majoritária do país, a negativa maliciosa do pai é uma violação do direito ao nome, à honra e a intimidade, o que causa um dano moral. Corroborando com esse entendimento, decidiu a CNCiv, Sala L, 23.XII.1994, LL, 1995 - E - 10: "Transitar por la vida sin más apellido que el materno y sin poder alegar la paternidad, causa em cualquier persona um daño psíquico marcado" (MADALENO, 2011, p 370 - nota de rodapé). Em tradução livre: Transitar pela vida somente com o sobrenome materno e sem poder alegar a paternidade causa em qualquer pessoa um dano psíquico marcado.

Com base no analisado, uma vez verificada a conduta culposa e consciente, o dano e o nexo de causalidade, torna-se possível caracterizar os três elementos da responsabilidade civil subjetiva. Com isso se configura o dever de indenizar, e consequente direito aos danos morais.

\section{3 - Danos Morais por Abandono Afetivo do Pai Adimplente de Alimentos}

É possível que após a sentença que reconhece a paternidade o genitor mantenha uma conduta negligente com o filho. Muitas vezes, pode haver o adimplemento do pagamento da pensão alimentícia fixada, mas a insistência em negar ao rebento todo tipo de assistência imaterial.

Abandonando afetivamente o filho, o genitor viola o dever de educação inerente ao poder familiar, exposto no início do presente capítulo. Conforme observado, é impositivo que os pais forneçam assistência 
psicológica e afetiva de modo a propiciar ao rebento condições para seu pleno desenvolvimento como pessoa.

A formação moral do indivíduo está intimamente relacionada com o suporte imaterial que lhe foi oferecido ao longo de sua vida. Obviamente, aqui não se adota a postura determinista e leviana de afirmar que pessoas que não tiveram uma base familiar sólida não serão indivíduos íntegros. Porém, é inegável que o convívio sadio com os pais é um direito dos filhos.

A outra face deste direito é o dever de educação e de visitação por parte dos pais. Se no passado as visitas já foram vistas como uma faculdade do genitor não guardião, atualmente constituem um direito-dever.

Além disso, em função das transformações no panorama social e jurídico, é certo que o direito de visitação tem a finalidade precípua de proteger os filhos, se caracterizando acima de tudo como um direito dos mesmos. É possível perceber que o convívio paterno-filial é fundamental para possibilitar um crescimento permeado por menos sentimentos como rejeição, insegurança e carência.

É certo que o ordenamento jurídico há tempos deixou de se preocupar com aspectos exclusivamente patrimoniais, e passou a tutelar questões afetivas. $\mathrm{O}$ afeto e o cuidado terem adquirido valor jurídico representa um corolário da transformação.

Ante ao exposto, pode-se concluir que aquele que infringe um dever do poder familiar, incutindo sentimentos de rejeição em sua prole, deve responder por isso. Apesar de não ser unanime, a possibilidade de indenização por danos morais nesses casos é defendida por parte da doutrina e da jurisprudência.

Corroborando com este entendimento, recentemente o Superior Tribunal de Justiça proferiu uma decisão inédita no sentido de reconhecer a possibilidade de danos morais por abandono afetivo. Este acórdão 
simboliza uma mudança de paradigma, pois até então o STJ se posicionava de forma diametralmente oposta. Por isso, o caso merece um estudo mais aprofundado que será realizado no tópico 5.4.

Sob o aspecto doutrinário, pode-se destacar Giselda Hironaka como uma das defensoras da tese. A professora acredita que a condenação ao pagamento de danos morais também possui um cunho educativo, no sentido de dissuadir outros pais a praticarem a mesma conduta. Nas palavras da mesma:

Ora, como já se mencionou que a condenação aplicável a tais casos tem duas relevantes funções, além da compensatória, que são funções punitiva e dissuasória, nada obsta que uma indenização de natureza não monetária, por certo, seria uma providência que afastaria essa conotação pejorativa, diga-se assim, dos casos justos - justos também pelo fato de que a irresponsabilidade social do pai da ou mãe ausente coloca em exposição prejudicial a sociedade como um todo, conforme antes se referiu. (HIRONAKA, 2007, s/p)

No mesmo sentido se posiciona Rolf Madaleno:

E, embora possa ser até dito que não há como o Judiciário obrigar a amar, também deve ser considerado que o Judiciário não pode se omitir de tentar, buscando de uma vez por todas acabar com essa cultura da impunidade que grassa no sistema jurídico brasileiro desde o tempo em que as visitas se configuravam como um direito do adulto e não como um evidente e incontestável dever que têm os pais de assegurar aos filhos a convivência familiar (...). A condenação de hoje pelo dano moral causado no passado, tem imensurável valor propedêutico para evitar arrefecer o abandono afetivo do futuro, para que os pais irresponsáveis pensem duas vezes antes de usar seus filhos como instrumento de vingança de suas frustrações amorosas (...).

O ressarcimento pecuniário não terá a função de compensar, mas cuidará apenas de certificar no tempo a nefasta existência desse imoral e covarde abandono do pai, e muito provavelmente, servirá de exemplo e alerta para os próximos abandonos, bem ao sabor da moderna doutrina que trata dos danos punitivos que são concedidos com uma finalidade dissuasória, preventiva e desincentivadora". (MADALENO, 2011, p. 377).

Por fim, faz-se necessário destacar que Maria Berenice Dias também acredita no valor punitivo-dissuasório do dano moral no caso em análise, conforme se observa: 
Dessa forma, o dano à dignidade humana do filho em estágio de formação deve ser passível de reparação material, não apenas para que os deveres parentais deliberadamente omitidos não fiquem impunes, mas, principalmente, para que, no futuro, qualquer inclinação ao irresponsável abandono possa ser dissuadida pela firme posição do Judiciário, ao mostrar que o afeto tem um preço muito alto na nova configuração familiar. (DIAS, 2010, p. 451 - grifo da autora).

Através dos trechos destacados é possível perceber que o dano moral por abandono afetivo teria a dupla função de fornecer um aparo financeiro para aquele que sofreu com a rejeição paterna, e também punir o genitor, desestimulado condutas idênticas. Esta segunda finalidade é derivada dos punitive damages, que, apesar de terem origem romana, foram muito desenvolvidos pelo direito norte americano e estão sendo bastante utilizados em nosso ordenamento.

Para defender a tese favorável à possibilidade de danos morais por abandono afetivo do pai adimplente de alimentos, é interessante destacar também o posicionamento de Fabio Baubab Boschi, que constrói uma argumentação baseada em fundamentos legais. Para justificar sua tese, o autor faz referencia a garantia da integral formação da personalidade dos filhos, previsto nos $3^{\circ}$ e $4^{\circ}$ do ECA e também no artigo 227 da Constituição Federal. Além disso, também alude ao exercício responsável da paternidade e consequente dever de visitação, dispostos nos artigos $226, \S 7^{\circ}$ e 229 de nossa Carta Magna e no artigo 1634, I e II do Código Civil atual.

A despeito de ser um entendimento interessante, em uma análise mais aprofundada não há como negar que os direitos a que o autor faz alusão são reflexos dos princípios citados anteriormente.

Sob o aspecto jurisprudencial, a Comarca de Capão da Canoa, RS, foi a responsável pela ação pioneira sobre o tema. No caso, julgado no ano de 2003, o juiz Mario Romano Maggioni decidiu pela condenação do genitor ao pagamento de 200 salários mínimos a título de indenização por abandono afetivo. A seguir, um trecho da sentença:

De se salientar que aos pais incumbe o dever de sustento, guarda e educação dos filhos (art. 22 da Lei no. 8.069/90). A educação abrange não somente a 
escolaridade, mas também a convivência familiar, o afeto, amor,carinho, ir ao parque, jogar futebol, brincar, passear, visitar, estabelecer paradigmas, criar condições para que a criança se auto-afirme. Desnecessário discorrer acerca da importância do pai no desenvolvimento da criança. A ausência, o descaso e a rejeição do pai em relação ao filho recém-nascido ou em desenvolvimento violam a sua honra e a sua imagem. (Juiz Mario Romano Maggioni. $2^{\mathrm{a}}$. Vara. Comarca de Capão da Canoa. Proc.no. 14/1020012032-0, 15.09.2003).

Depois desta inovadora decisão da Comarca de Capão da Canoa, o Superior Tribunal de Justiça, em atitude oposta a que adotou recentemente, negou a possibilidade de conceder os danos morais na hipótese de abandono afetivo em outra demanda similar. A ação que o STJ encerrou ao proferir esta decisão teve início no Estado de Minas Gerais, e a sentença de $1^{\text {a }}$ instancia julgou improcedente o pleito de danos morais, alegando que não haveria prova do prejuízo sofrido.

Então, a parte prejudicada recorreu, ocasião em que a $7^{\mathrm{a}}$. Câmara Cível do Tribunal de Alçada de Minas Gerais reformou a decisão, defendendo ser possível a indenização por ter havido uma ofensa ao princípio da dignidade da pessoa humana, conforme se observa no trecho do acórdão prolatado:

INDENIZAÇÃO DANOS MORAIS- RELAÇÃO PATERNO-FILIALPRINCÍPIO DA DIGNIDADE DA PESSOA HUMANA- PRINCÍPIO DA AFETIVIDADE.

A dor sofrida pelo filho, em virtude de abandono paterno, que a privou do direito à convivência, ao amparo afetivo, moral e psíquico, deve ser indenizável, com fulcro no princípio da dignidade da pessoa humana. (TA/MG, Sétima Câmara Cível, Apelação Cível nº 408.550.5, Belo Horizonte, Rel. Juiz Unias Filho, 01 abr. 2004).

Ocorre que, novamente, houve inconformismo, o que levou a necessidade de um posicionamento do STJ sobre o tema. A $4^{\text {a }}$ Turma do Superior Tribunal de Justiça, por sua vez, decidiu que os danos morais não se configuravam, haja vista ter entendido que a única sanção aplicável no caso é a perda do poder familiar por parte do genitor que abandona, pois não seria possível aplicar os artigos 186 e 927 do atual Código Civil. Destaca-se a ementa do caso: 
Responsabilidade civil - Abandono moral - Reparação - Danos morais Impossibilidade. A indenização por dano moral pressupõe a prática de ato ilícito, não rendendo ensejo a aplicabilidade da norma do art. 159 do CC/1916 (arts. 186 e 927, CC/2002) o abandono afetivo, incapaz de reparação pecuniária. Recurso especial conhecido e provido (STJ, Recurso Especial no 757.411/MG, Rel. Min. Fernando Gonçalves, Brasília, 29 nov. 2005).

O entendimento foi confirmado pelo Supremo Tribunal Federal. Porém, é frágil a argumentação de que a perda do poder familiar seria uma sanção não merece prosperar pois se o pai nunca manifestou interesse em cuidar do filho, a perda do poder familiar em nada irá lhe afetar. Em casos extremos, esta suposta punição seria até mesmo um motivo de alívio, pois o pai teria menos uma obrigação. Além disso, nos dias atuais é pacífico que a função precípua do poder familiar é proteger os direitos dos filhos.

Corroborando com o entendimento de a decisão exposta estar em desacordo com o atual ambiente jurídico, pode-se citar um recente acórdão em que o STJ adotou postura diversa. Assim, durante a elaboração do presente estudo, o Tribunal proferiu a sua primeira decisão julgando procedente a possibilidade de danos morais em um caso semelhante, objeto de exame do tópico a seguir.

\section{4 - O Julgamento Paradigmático}

No início do mês de maio teve grande repercussão social e midiática um julgamento do Superior Tribunal de Justiça que condenou o pai ao pagamento de $\mathrm{R} \$ 200.000,00$ (duzentos mil reais) para sua filha, a título de indenização por abandono afetivo. Trata-se de uma decisão inédita que pode ser um precedente para outras de mesmo teor.

Para uma melhor compreensão do julgamento, é imperioso elucidar o andamento processual até a apreciação da demanda pelo STJ. A filha, uma professora de 38 (trinta e oito) anos, ingressou com uma ação pleiteando o 
reconhecimento de danos morais por abandono afetivo em face de seu genitor, dono de uma rede de postos de gasolina.

A autora argumenta que sempre foi negligenciada pelo réu, e até mesmo o reconhecimento da paternidade teve que ocorrer pela via judicial. Apesar de residirem em cidades vizinhas, ela em Votorantim e ele em Sorocaba, o genitor nunca lhe forneceu cuidado, atenção, carinho ou qualquer tipo de aconselhamento.

Ademais, a professora aduz que sempre foi preterida diante dos outros filhos de seu genitor, o que lhe causou um sentimento de rejeição que poderia ter afetado sua dignidade. Prova desse tratamento diferenciado é o fato de o réu ter adquirido propriedades em nome dos outros filhos, objetivando fraudar uma futura partilha de bens.

Por fim, apesar de adimplir o pagamento da pensão, o que só foi feito após sentença judicial, a autora alega que nunca teve nenhum tipo de ajuda complementar para pagar médicos, remédios ou livros. Conforme já observado, o réu é dono de postos de gasolina em quatro Estados, e, portanto, o custeio dessas despesas seria possível de acordo com o binômio necessidade $\mathrm{X}$ possibilidade.

O réu, por sua vez, argui que não abandonou a filha. De acordo com a sua versão dos fatos, a dificuldade de relacionamento se deve à mãe da autora, que teria sido agressiva nas diversas tentativas de aproximação do genitor.

$\mathrm{O}$ requerido argumenta também que, ainda que o suposto abandono seja verídico, não há previsão legal de punição financeira para este tipo de situação. Ante a ausência de previsão legislativa, a perda do poder familiar seria a única sanção aplicável. 
Para concluir, o genitor alude a jurisprudência do STJ que, até então, não reconhecia a possibilidade de danos morais por abandono afetivo, conforme mencionado anteriormente.

Em primeira instância o pedido autoral foi julgado improcedente, pois o juiz entendeu que o distanciamento entre pai e filha ocorreu em virtude das atitudes da genitora da autora. Inconformada, a requerente apelou da decisão.

Em sede de recurso, o Tribunal de Justiça de São Paulo reformou a decisão, condenando o réu a pagar $\mathrm{R} \$ 415.000,00$ (quatrocentos e quinze mil reais) como indenização. O Tribunal entendeu que houve o abandono afetivo e que inexiste vedação legal para aplicá-lo no caso em tela. Segue a ementa do julgado:

AÇÃO DE INDENIZAÇÃO. DANOS MORAIS E MATERIAIS. FILHA HAVIDA DE RELAÇÃO AMOROSA ANTERIOR. ABANDONO MORAL E MATERIAL. PATERNIDADE RECONHECIDA JUDICIALMENTE. PAGAMENTO DA PENSÃO ARBITRADA EM DOIS SALÁRIOS MÍNIMOS ATÉ A MAIORIDADE. ALIMENTANTE ABASTADO E PRÓSPERO. IMPROCEDÊNCIA. APELAÇÃO. RECURSO PARCIALMENTE PROVIDO. (STJ, Recurso Especial n 1.159.242/SP, Rel. Min. Nancy Andrighi, Brasília, 24 abr. 2012)

Então, foi o genitor quem discordou da decisão e decidiu recorrer ao Superior Tribunal de Justiça através do Recurso Especial. Nesta ocasião a Terceira Turma exarou o polemico acórdão que condenou o pai ao pagamento de $\mathrm{R} \$ 200.000,00$ (duzentos mil reais) para sua filha.

A Ministra Nancy Andrighi foi a relatora, e se posicionou pela manutenção parcial do acórdão do TJ/SP, reconhecendo a existência dos danos morais, mas pugnando pela redução do valor atribuído aos mesmos. De acordo com a Ministra, não há vedação legal para se aplicar os institutos da Responsabilidade Civil no âmbito do Direito de Família, até porque, os próprios dispositivos que regulam a matéria não impõe restrições, conforme se extrai de seu voto: 
Ao revés, os textos legais que regulam a matéria (art. 5, ${ }^{\circ} \mathrm{V}$ e $\mathrm{X}$ da CF e arts. 186 e 927 do CC-02) tratam do tema de maneira ampla e irrestrita, de onde é possível se inferir que regulam, inclusive, as relações nascidas dentro de um núcleo familiar, em suas diversas formas.

Assim, a questão - que em nada contribui para uma correta aplicação da disciplina relativa ao dano moral - deve ser superada com uma interpretação técnica e sistemática do Direito aplicado à espécie, que não pode deixar de ocorrer, mesmo ante os intrincados meandros das relações familiares. (STJ, Recurso Especial $n^{\circ}$ 1.159.242/SP, Rel. Min. Nancy Andrighi, Brasília, 24 abr. 2012)

Além disso, Nancy Andrighi aduz também que a perda do poder familiar não exclui a possibilidade de serem aplicadas sanções com caráter indenizatório. Nos dizeres da mesma:

Nota-se, contudo, que a perda do pátrio poder não suprime, nem afasta, a possibilidade de indenizações ou compensações, porque tem como objetivo primário resguardar a integridade do menor, ofertando-lhe, por outros meios, a criação e educação negada pelos genitores, e nunca compensar os prejuízos advindos do malcuidado recebido pelos filhos. (STJ, Recurso Especial $n^{\circ}$ 1.159.242/SP, Rel. Min. Nancy Andrighi, Brasília, 24 abr. 2012)

Prosseguindo, a Ministra reconhece a dificuldade de se caracterizar os três elementos da responsabilidade civil subjetiva nas relações familiaristas. No entanto, ressalta que o cerne do problema está em se ter em mente que ser pai implica na assunção de uma série de responsabilidades que possuem previsão legal. Dessa forma, quando o afeto não é suficiente para fazer com que os pais cumpram voluntariamente com essas obrigações, há necessidade de buscar o vínculo legal para tentar amparar o filho.

Sob esse aspecto, indiscutível o vínculo não apenas afetivo, mas também legal que une pais e filhos, sendo monótono o entendimento doutrinário de que, entre os deveres inerentes ao poder familiar, destacam-se o dever de convívio, de cuidado, de criação e educação dos filhos, vetores que, por óbvio, envolvem a necessária transmissão de atenção e o acompanhamento do desenvolvimento sócio-psicológico da criança.

E é esse vínculo que deve ser buscado e mensurado, para garantir a proteção do filho quando o sentimento for tão tênue a ponto de não sustentarem, por si só, a manutenção física e psíquica do filho, por seus pais - biológicos ou não. (STJ, Recurso Especial no 1.159.242/SP, Rel. Min. Nancy Andrighi, Brasília, 24 abr. 2012) 
A relatora faz referencia ainda ao fato de o cuidado estar se tornando um valor jurídico, o que se comprova pelo crescente número de publicações sobre o tema. Em função disso, conforme já exposto, os deveres dos pais extrapolam a órbita das necessidades meramente físicas, chamadas de "necessarium vitae", englobando também o diálogo, os incentivos, o tratamento igualitário a toda prole, entre outros aspectos imateriais.

Assim, Nancy Andrighi esclarece que o que está sendo discutido não é o dever de amar, haja vista o amor possuir na sua essência a voluntariedade, sendo impossível impor um sentimento a quem quer que seja. O que deve ser considerado é o dever de cuidado, que se materializa na presença do genitor, e nas condutas citadas anteriormente. É através do cuidado que se constrói a base para o integral desenvolvimento da pessoa humana, e por isso este é tão necessário. De acordo com os ensinamentos da relatora:

\footnotetext{
Vê-se hoje nas normas constitucionais a máxima amplitude possível e, em paralelo, a cristalização do entendimento, no âmbito científico, do que já era empiricamente percebido: o cuidado é fundamental para a formação do menor e do adolescente; ganha o debate contornos mais técnicos, pois não se discute mais a mensuração do intangível - o amor - mas, sim, a verificação do cumprimento, descumprimento, ou parcial cumprimento, de uma obrigação legal: cuidar. (STJ, Recurso Especial no 1.159.242/SP, Rel. Min. Nancy Andrighi, Brasília, 24 abr. 2012)
}

Ademais, a Ministra esclarece que não é imprescindível que o dano seja comprovado através de laudo formulado por psicólogo, considerando que a pessoa pode ter sofrido e superado os efeitos danosos da ausência paterna, conforme ocorreu com a professora do caso em tela. A comprovação é dispensável porque trata-se de um dano in re ipsa, possível de ser presumido.

Concluindo, a relatora julga que o valor de $\mathrm{R} \$ 415.000,00$ (quatrocentos e quinze mil reais) é excessivo, razão pela qual acredita que deve ser reduzido para $\mathrm{R} \$ 200.000,000$ (duzentos mil reais). 
Completamente diverso foi o voto do Ministro Massami Uyeda, que entendeu ser impossível verificar a incidência de danos morais na presente lide, e por isso deu provimento ao recurso e afastou a condenação. De acordo com seu entendimento, ao reconhecer os danos morais na hipótese, estar-se-ia criando um precedente para que qualquer mágoa fosse motivo suficiente para conceder uma indenização. Nas palavras do Ministro:

O voto de V. Exa. é pioneiro, Sra. Ministra Nancy Andrighi, mas também atento para a seguinte circunstância: se abrirmos essa porta como Tribunal de unificação jurisprudencial de interpretação da lei federal -e, aqui, no caso, é o Código Civil -, e V. Exa. também cita a Constituição, na qual um dos pilares do fundamento do Estado é a preservação da dignidade da pessoa humana, também não podemos esquecer que a interpretação dos princípios constitucionais requer razoabilidade, proporcionalidade. E, se for assim, não haverá mais tranquilidade. Vamos causar aquilo que o Sr. Ministro Sidnei Beneti sempre fala: estabelecer uma cizânia dentro da família, porque essa pessoa, certamente, se o pai é abastado, irá concorrer na herança no dia em que ele faltar, ou esse pai negligente, vamos dizer. (STJ, Recurso Especial $\mathrm{n}^{\mathbf{0}}$ 1.159.242/SP, Rel. Min. Nancy Andrighi, Brasília, 24 abr. 2012)

Através do voto do Ministro pode-se perceber um argumento muito utilizado pelos que são contrários a concessão de danos morais por abandono afetivo: o temor de gerar um precedente, fazendo com que a indenização seja banalizada e aplicada em qualquer caso.

Tal temor não merece prosperar. O que está sendo julgado não é uma hipótese de mero desconforto ou tristeza, sentimentos que fazem parte da vida de todos. Aqui, se trata de uma filha que foi preterida diante de seus irmãos, nunca recebeu qualquer auxílio imaterial e ainda teve que buscar o reconhecimento e o pagamento da pensão pela via judicial. Com sua atitude, o genitor praticou uma conduta na modalidade omissiva, quando podia e devia ter agido de forma distinta.

Nesse ponto, faz-se necessário retornar a tese de Maria Celina Bodin de Morais, exposta no terceiro capítulo. Em virtude da conduta do pai, a filha não sofreu um mero sentimento de tristeza, ela foi preterida diante de um grupo e teve a sua integridade psicofísica afetada, podendo-se afirmar que houve uma violação ao princípio da dignidade da pessoa humana. 
Corroborando com o entendimento favorável a concessão de danos morais no caso, está o posicionamento do Ministro Sidnei Beneti, que proferiu o Voto-Vista. Este reconheceu a configuração do dano moral na hipótese, partilhando de alguns argumentos da Ministra Nancy Andrighi. Entretanto, julgou que a culpa pelo afastamento não ocorreu por culpa exclusiva do pai, sendo a mãe em parte responsável. Assim, tendo em mente que o valor da indenização deve ser proporcional à ação ou omissão do agente, também se manifestou pela redução do montante para $\mathrm{R} \$$ 200.000,00 (duzentos mil reais), o que se verifica a seguir:

\begin{abstract}
Deve-se, pois, proporcionalizar a indenização pelo abandono afetivo da filha autora à ação e omissão efetiva do genitor autor, descontando-se a parcela de responsabilidade da genitora, evidente nos fatos reconhecidos pela sentença e pelo Acórdão - e em que pese à compreensão humana para com a situação da genitora, que, segundo os autos, teve, por oito anos, relacionamento pré-conjugal com o requerido, ora Recorrente, que veio a deixá-la grávida pouco antes do nascimento da filha autora, a qual só veio a ter a paternidade reconhecida por sentença judicial após longa resistência do genitor em duradouro processo. (STJ, Recurso Especial nº 1.159.242/SP, Rel. Min. Nancy Andrighi, Brasília, 24 abr. 2012)
\end{abstract}

O genitor discordou do acórdão e afirmou que vai recorrer ao Supremo Tribunal Federal. Porém, é inegável que o STJ exarou uma decisão sensível às mudanças citadas no primeiro capítulo, e em conformidade com os princípios que regem o Direito de Família atualmente.

Examinando os votos, especialmente o da Ministra Nancy Andrighi, é possível perceber que situações como a descrita extrapolam a esfera meramente patrimonial, conferindo ao dinheiro as já citadas dimensões simbólicas. Para ilustrar a questão, é elucidativo o depoimento da autora da ação que foi analisada neste tópico, em entrevista fornecida a uma emissora de TV:

"Eu fiquei muito feliz, porque eu tenho certeza que muitas pessoas que vivem a mesma situação que eu poderão ser beneficiadas: muitas crianças, muitos adultos. Não é o dinheiro, tanto que o dinheiro é uma quantia, você viu. Não é o 
dinheiro, a minha questão é uma questão emocional, uma questão muito além disso. Muito além."

Portanto, tendo em mente o dever de educação inerente ao poder familiar e a preponderância de todos os princípios mencionados, pode-se dizer que negar o direito aos danos morais por abandono afetivo caracteriza uma postura retrógrada e em dissonância com a evolução do panorama jurídico.

\footnotetext{
${ }^{1}$ Trecho de entrevista concedida por L.N.O.S. ao programa Jornal Hoje, transmitido pela Rede Globo de Televisão na edição do dia 04/05/2012
} 


\section{CONCLUSÃO}

Erigido sobre os pilares de uma análise doutrinaria e jurisprudencial, o presente trabalho teve como objetivo defender a possibilidade de incidência dos danos morais nos casos de abandono afetivo e de negação ou protelamento voluntário do reconhecimento da paternidade.

Através de uma abordagem histórico-legislativa, foi demonstrado que o foco do Direito de Família deslocou-se do patrimônio para a pessoa. No entanto, ainda é possível observar um número alarmante de crianças e adolescentes que crescem alijados do direito a uma convivência saudável com os genitores.

Esta ausência de convívio pode gerar no filho um forte sentimento de rejeição, acarretando problemas psicológicos capazes de afetar seu integral desenvolvimento. Contudo, ainda que este sentimento seja superado, a prestação de assistência imaterial consiste em um verdadeiro dever inerente ao poder familiar.

Além disso, pôde-se constatar que a rejeição paterna voluntária caracteriza uma violação aos princípios da dignidade da pessoa humana, da afetividade, da solidariedade, da igualdade da prole e do melhor interesse da criança.

Observou-se também que o cuidado vem adquirindo valor jurídico, pois, embora ainda não seja considerado um princípio, tem sido utilizado como fundamento de expressivos julgados e possui respaldo doutrinário. Exemplo disso foi o recente julgamento do Superior Tribunal de Justiça, amplamente discutido no presente estudo, que reconheceu a possibilidade de danos morais por abandono afetivo. 
Todavia, apesar de o STJ ter admitido a incidência de danos morais no caso supracitado, a jurisprudência ainda é vacilante. Prova disso é o fato de esta ter sido a primeira vez que o referido Tribunal se posicionou neste sentido, caracterizando um importante precedente.

Outrossim, comprovou-se que os três elementos caracterizadores da responsabilidade civil subjetiva - dano, culpa e nexo causal - incidem nas hipóteses que ora se analisa. Neste ponto, é imperioso ressaltar que o requisito da culpa é fundamental, haja vista a impossibilidade de responsabilizar aquele que não sabia da existência de um filho.

Verificada a culpa na conduta do genitor, emerge a necessidade de se desestimular outras atitudes similares. Assim, evidenciou-se que o caráter punitivo-pedagógico dos danos morais adéqua-se ao processo de evolução do cenário jurídico na direção de privilegiar o afeto e o cuidado nas relações familiares.

Foi exposto ainda que a tese contrária ao reconhecimento de danos morais nas hipóteses abordadas aduz que é imoral atribuir um valor pecuniário ao amor. Entretanto, o trabalho não teve a pretensão de monetarizar o afeto, e sim comprovar que a convivência entre pai e filho é um direito e, como tal, aquele que o viola tem o dever de reparar o dano.

Em síntese, conclui-se que a condenação ao pagamento de danos morais nos casos de protelamento de má-fé da demanda investigatória e o abandono afetivo por parte do genitor se configura não somente como uma possibilidade, mas também como uma tendência. Esta tendência vai ao encontro das transformações sociais que culminaram com a evolução do instituto familiar e do ordenamento jurídico, mais adequados ao pluralismo que marca a realidade atual. 


\section{REFERÊNCIAS}

BRAGANHOLO, Beatriz Helena. Algumas Reflexões Acerca da Evolução, Crise e Constitucionalidade do Direito de Família Brasileiro. In Revista Brasileira de Direito de Direito de Família, Porto Alegre: Síntese e IBDFAM, v. 28, p. 71, fev./mar. 2005.

BRASIL, Censo Escolar de 2009.

BRASIL. Constituição (1988). Constituição da Republica Federativa do Brasil. Brasília, DF: Senado Federal.

BRASIL, Código Civil de 1916, institui o Código dos Estados Unidos do Brasil, publicado em 2 de janeiro de 1916.

BRASIL, Código Civil de 2002, institui o Código Civil, publicado em 11 de janeiro de 2001.

BRASIL, Lei 883/1949, dispõe sobre o reconhecimento de filhos ilegítimos, publicada no DOFC em 26 de outubro de 1949.

BRASIL, Lei 4.121/1962, dispõe sobre a situação jurídica da mulher casada, publicada no DOFC em 03 de setembro de 1962

BRASIL, Lei 12.004/2009, altera a lei $\mathrm{n}^{\circ}$ 8.650, publicada no D.O.U. em 30 de julho de 2009.

BRASIL, Lei 12.010/2009, dispõe sobre adoção; altera as leis $\mathrm{n}^{\circ} 8.069$ e 8.560; revoga dispositivos da lei $\mathrm{n}^{\mathrm{o}}$ 10.406; publicada no DOU em 04 de agosto de 2009 .

BRASIL, Provimento ${ }^{\circ} 12$ do Conselho Nacional de Justiça.

BRASIL, Provimento n ${ }^{\circ} 16$ do Conselho Nacional de Justiça.

CAHALI, Yussef Said. Dano Moral. $3^{\mathrm{a}}$ ed.. São Paulo: Revista dos Tribunais, 2005.

CAROSSI, Eliane Goulart Martins. O Valor Jurídico do Afeto na Atual Ordem Civil-Constitucional Brasileira. Disponível em <http://www.ibdfam.org.br>. Acesso em 15 de abril de 2012.

CAVALIERI FILHO, Sergio. Programa de Responsabilidade Civil. 8. ed. São Paulo: Malheiros, 2008. 
COSTA, Lívia Ronconi. Notas sobre a filiação. Disponível em <http://www.ibdfam.org.br>. Acesso em 28 de março de 2012.

DIAS, Maria Berenice. Filhos da mãe, até quando? . Disponível em <http://www.ibdfam.org.br>. Acesso em 28 de março de 2012.

DIAS, Maria Berenice. Manual de Direito das Famílias. $7^{\mathfrak{a}}$ ed.. São Paulo: Revista dos Tribunais, 2010.

DIAS, Maria Berenice. Pai Ausente. Disponível em $<$ http://www.ibdfam.org.br>. Acesso em 28 de março de 2012.

FACHIN, Luis Edson. Da Paternidade: relação biológica e afetiva. Belo Horizonte: Del Rey, 1996.

GAMA, Guilherme Calmon Nogueira da; GUERRA, Leandro dos Santos. Função Social da Família. In: GAMA, Guilherme Calmon Nogueira da. Função Social no Direito Civil. São Paulo: Atlas, 2007.

HIRONAKA, Giselda Maria Fernandes Novaes. Pressupostos, elementos e limites do dever de indenizar por abandono afetivo. Disponível em $<$ http://www.ibdfam.org.br/ >. Acesso em 02 de fevereiro de 2012.

LEAL, Bruno Bianco. Entendendo a doutrina dos "punitive damages". Disponível em <http://www.sosconcurseiros.com.br>. Acesso em 13 de maio de 2012.

LEITÃO, Manuela Nishida; TOMASZEWSKI, Adauto de Almeida. Filiação socioafetiva: A posse do estado de filho como critério indicador da relação paterno-filial e o direito à origem genética. Revista Jurídica da UniFil, Ano III - nº 3, 2006.

LOPES, Maria Graciete Carramate. Conheça a determinação genética dos grupos do sistema ABO. Disponível em $<$ http://www.educacao.uol.com.br/biologia $>$. Acesso em 25 de abril de 2012.

MADALENO, Rolf. Curso de Direito de Família. $4^{\mathrm{a}}$ ed.. Rio de Janeiro: Forense, 2011.

MADALENO, Rolf. Direito de Família: aspectos polêmicos. $2^{\mathrm{a}}$ ed.. Porto Alegre: Livraria do Advogado, 1999.

PEREIRA, Caio Mário da Silva. Instituições de Direito Civil. Volume V. $18^{\mathrm{a}}$ ed. Rio de Janeiro: Forense, 2010.

PEREIRA, Rodrigo da Cunha. Afeto, Ética, Família e o novo código civil. Belo Horizonte: Del Rey, 2004. 
SOUZA, Vanessa Ribeiro Correa Sampaio. Reconstruindo a Paternidade: a recusa do filho ao exame de DNA. Campos dos Goytacazes: Faculdade de Direito de Campos, 2005.

STJ, Recurso Especial n ${ }^{\circ} 1.159 .242 / S P$ (2009/0193701-9), Rel. Min. Nancy Andrighi, Brasília, 24 abr. 2012.

STJ, Recurso Especial n ${ }^{\circ}$ 757.411/MG, Rel. Min. Fernando Gonçalves, Brasília, 29 nov. 2005.

TA/MG, Sétima Câmara Cível, Apelação Cível nº 408.550.5, Belo Horizonte, Rel. Juiz Unias Filho, 01 abr. 2004.

TEPEDINO, Gustavo; BARBOZA, Heloisa Helena; Moraes, Maria Celina Bodin de. Código Civil Interpretado conforme a Constituição da República. Volume I. $2^{\mathrm{a}}$ ed.. Rio de Janeiro: Renovar, 2007.

TJ/RS, Oitava Câmara Cível, Apelação Cível no 70046188512, Rel. Ricardo Moreira Lins Pastl, Rio Grande do Sul, 16 fev. 2012.

TJ/RS, Quinta Câmara Cível, Apelação Cível no 596125757, Rel. Araken de Assis, Rio Grande do Sul, 15 ago. 1996. 